\title{
Microfabric diversity and grain shape analysis of fault rocks from the selected areas of the Western Tatra Mountains
}

\author{
Maciej KANIA ${ }^{1, *}$ \\ 1 Institute of Geological Sciences, Jagiellonian University, Oleandry 2a, 30-063 Kraków, Poland
}

Kania M. (2014) Microfabric diversity and grain shape analysis of fault rocks from the selected areas of the Western Tatra Mountains. Geological Quarterly, 58 (1): 3-18, doi: 10.7306/gq.1129

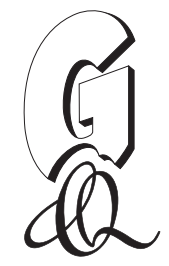

\begin{abstract}
Fault rocks in brittle and brittle-ductile shear zones played a key role in the evolution of the Western Tatra Mountains crystalline rocks (Poland-Slovakia). Microfabrics of these rocks, including grain shape analyses, were investigated in the six areas of the Western Tatra Mountains. Based on studies of thin sections, 14 types of fault rock microfabric are distinguished, according to the following criteria: (a) the presence and abundance levels of a cataclastic matrix and (b) the presence and form of a preferred orientation features. General tendencies observed in these areas indicate southwards increasing non-coaxial deformation as well as the domination of ultracataclasites or ultramylonites to phyllonites in areas with negative relief (e.g., sedlo Zabrat' Pass, Dziurawa Przełęcz Pass). A model of shear zone evolution embracing following three stages is proposed: (1) deformation partitioning and block-controlled cataclastic flow, (2) matrix-controlled cataclastic flow, (3) selective leaching and deposition of silica, leading to the formation of softened and hardened deformation domains respectively. These microstructural observations were supported by statistical analyses of the grain shape indicators (compactness, isometry, ellipticity, solidity, convexity). Two trends of relationships between compactness and convexity were noted: the first, horizontal on the correlation diagrams, was interpreted as an effect of rapid cataclasis and then sericitization, the second, with a strongly negative correlation coefficient, was considered as an effect of long-term cataclastic flow. The different microfabric data and microstructural interpretations described in this paper are consistent with a new model of the tectonic history of the Western Tatra Mountains evolution, with an important role for a non-coaxial deformation during Alpine orogeny in brittle and brittle-ductile conditions.
\end{abstract}

Key words: microfabrics, grain shape analysis, fault rocks, shear zones, Western Carpathians, Western Tatra Mountains.

\section{INTRODUCTION}

The processes of non-coaxial shearing may induce structural, mineralogical and geochemical modifications in deformed rocks. A wide range of different products of these heterogeneous processes can be named "fault rocks" (Brodie et al., 2007). Their diversity is a derivative of many different factors, such as: local stress components, physical conditions of the deformation processes, chemical composition and activity of the fluids in the shear zone, and rheological properties of the rocks undergoing deformations (Sibson, 1977; Passchier and Trouw, 2005). Even if deformation does not change the chemical or mineral composition of the rock, its microfabric can be affected. The term "microfabric" in this paper means the relative size, shape and spatial relationships between grains, internal features of grains in a rock, and their relative orientation (Passchier and Trouw, 2005; Brodie et al., 2007).

\section{*E-mail: maciej.kania@uj.edu.pl}

Received: July 31, 2013; accepted: September 23, 2013; first published online: November 14, 2013
Classifications of fault rocks is generally on a qualitative or semi-quantitative basis. The most important classification criterion is a distinction between rocks deformed in brittle and in ductile conditions (e.g., Sibson, 1977; Davis and Reynolds, 1996). In the first case the products of the deformation are tectonic breccias and cataclasites, in the second, they are mylonites. The most common factor is a ratio of matrix to larger, undisintegrated fragments of the rock (Sibson, 1977; Woodcock and Mort, 2008). However, it should be noted that these fragments may change their shape during deformation. The main processes responsible for these changes are: cataclastic flow embracing development of intragranular fractures and following slips and rotations, according to the local sense of shear, as well as pressure solution and dynamic recrystallization (Passchier and Trouw, 2005). These grain modifications can be described using a grain shape analysis method, based on the measurements of shape indicators in a thin section of the rock. Such method may be a source of information on the conditions and the mechanisms of deformation (e.g., Heilbronner and Keulen, 2006; Keulen et al., 2007). One of the advantages of this method is that data are easily obtained from photomicrographs (Bartozzi et al., 2000), and then can be analysed with statistical methods.

Shear zones with fault rocks are common features of the crystalline rocks across the whole Tatra Mountains, and especially the Western Tatra Mountains. These zones were earlier 
described as epidote-quartz and chlorite rocks (Michalik, 1958; Michalik and Guzik, 1959a, b) or as sericite-quartz rocks (Jaroszewski, 1965, 1967) and also as mylonitic greisens (Skupiński, 1975). Gawęda (2001) proposed eight vertical tectonic zones with mylonite. Cymerman (2011a) mapped numerous heterogeneous zones of the fault rocks in different areas of the Western Tatra Mountains, e.g., Rakoń, Wołowiec and Trzydniowiański Wierch mountains.

\section{GEOLOGICAL SETTING}

In the Western Carpathians three zones are classically distinguished: Outer, Central and Inner (e.g., Mahel', 1986; Plašienka, 1995). The Tatra Mountains form the northernmost and the highest massif of the Central Western Carpathians (Fig. 1). This rhomboidal massif is outlined by Alpine dislocations: the Subtatric, Ružbachy, Krowiarki and Choč faults (Bac-Mosza-

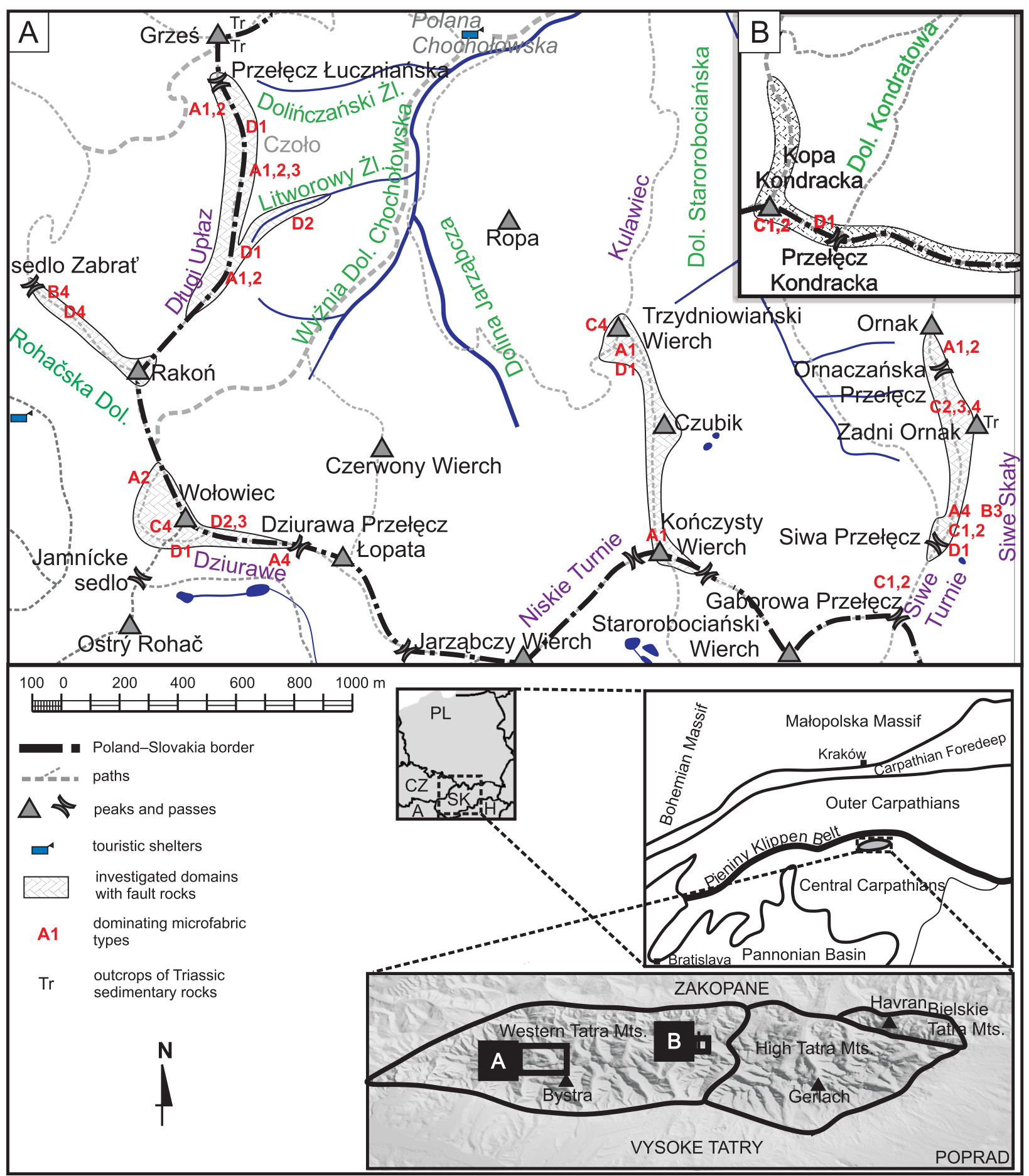

Fig. 1. Sketch-map of the Western Tatra Mountains and locations of the shear zones studied with the fault rocks 
szwili, 1993). The northern boundary of the Tatra Mountains is delimited by a contact with Central Carpathian Paleogene strata.

The Tatra Mountains crystalline core, together with its paraautochthonous sedimentary cover is included into the Tatricum tectono-facial unit (e.g., Plašienka, 2003). This unit was covered by sheared and overthrusted strata of the Fatricum and Hronicum basins, forming the Križna and Choč nappes, known also as Lower and Upper Subtatric nappes (Piotrowska, 2009; Uchman, 2009). The Miocene sub-horizontal E-W trending axis rotation of the Tatra Block (Jurewicz, 2005), resulted in the asymmetrical cross-section of the massif with its metamorphic and magmatic crystalline core in the south and Mesozoic sedimentary cover in the north.

Kohút and Janák (1994) distinguished the following granitoid types in the Tatra Mountains:

1 - a biotite-amphibole-quartz diorite, which forms only small bodies;

2 - the "High Tatra type" biotite granodiorite to tonalite transitional to a muscovite-biotite granodiorite, which occur only in the High Tatra Mountains;

3 - the "common Tatra type" biotite and muscovite-biotite granodiorite to granite, slightly porphyritic, which is the most abundant in plutonic rock the Western Tatra Mountains and forms most of its crystalline massifs;

4 - the "Goryczkowa type" porphyric granites to granodiorites with phenocrysts of pinkish K-feldspar, which occurs mainly in the marginal parts of the pluton, often in detached crystalline tectonic slices.

The magmatic (partially metamorphosed) rocks of the Western Tatra Mountains were formed during the following stages of Variscan magmatism: $405 \mathrm{Ma}$ intrusion of granites with 350-360 Ma metamorphism; 340-370 intrusion of the Roháče granodiorites; and 340 Ma syntectonic, sub-horizontal intrusion of leucogranites (alaskites) (Poller et al., 2000; Gawęda, 2001, 2007).

For the Western Tatra crystalline rocks massif, a model of two structural units was proposed (Janák, 1992, 1994; Faryad, 1999), where a lower structural unit, comprising mainly micaschists, is overthrust by an upper structural unit, comprising migmatites, orthogneisses and amphibolites. The rocks of the upper unit underwent two stages of metamorphism: first at pressures of $10-14 \mathrm{kbar}$ and temperatures of $700-800^{\circ} \mathrm{C}$, and secondly at pressures of 4-6 kbar and temperatures of 650-750 ${ }^{\circ} \mathrm{C}$ (Janák, 1994). A similar model of inversed metamorphism and Variscan development of two structural units was proposed also for the Polish part of the Western Tatra Mountains, with synkinematic intrusion of leucogranites (alaskites) between the two structural units (Gawęda, 2001). The Variscan tectonic exhumation of the Tatra Massif occurred in conditions of top-to-the south thrusting and E-W extension (Janàk et al., 1999).

\section{METHODS}

This paper is focused on the following six, relatively easy accessible areas of the Western Tatra Mountains (Fig. 1); from west to east:

1 - Długi Upłaz (Slovak - Dlhý úplaz) Ridge;

2 - Zabraty Ridge and sedlo Zabrat' Pass;

3 - Wołowiec (Slovak - Volovec) Mountain and Dziurawe (Slovak - Deravá) Ridge and Pass;

4 - Trzydniowiański, Czubik and Kończysty (Slovak Končistá) mountains;

5 - Ornak Ridge and Mountain, Siwa Przełęcz Pass and Siwe Turnie Ridge;
6 - Goryczkowa Czuba (Slovak - Goričkova kopa) Mountain and Kopa Kondracka (Slovak - Kondratova kopa) Mountain.

In these areas 103 exposures were investigated. Unoriented and oriented samples, taken from all exposures, were cut perpendicular to the foliation planes (if any) and parallel to the lineation, then thin sections were made.

Grain shape analysis was conducted as follows:

1. Making a series of thin section photomicrographs, which were merged to obtain a total area of not less than $20-30 \mathrm{~mm}^{2}$ (in most cases about $45 \mathrm{~mm}^{2}$, larger areas being used for rocks with larger grains). The photomicrographs were taken in plane-polarized light as well as with crossed polars. 17 thin sections with all observed microfabric types (see next section) were selected for detailed grain shape analysis.

2. Vectorization of the grain perimeters from 17 thin sections. This was manually conducted in JMicroVision software (Roduit, 2007). As Kruhl (2013) states “...for many cases the manual transformation of a structure to a binary pattern is still the best choice". No less than 50 grains were delimited in the each of the thin sections. In total, 1288 grains of quartz and feldspars were vectorized. In the case of a core-mantle structure, only the core was taken into consideration.

3. Calculation of the grain shape indicators, using built-in functions of JMicroVision. The detailed definitions of these indicators will be given in the next section.

4. Statistical analyses of the data obtained with Statsoft Statistica 10 and Microsoft Excel software.

The subdivision of the fault rocks applied in this paper (proto-, meso-, ultra- cataclasites/mylonites) is according to the classification by Woodcock and Mort (2008) where prefix protomeans a content up to $50 \%$ of matrix (grains $<0.1 \mathrm{~mm}$ ), mesomeans $50-90 \%$ of matrix and ultra- means more than $90 \%$ of matrix.

\section{GRAIN SHAPE INDICATORS}

Grain shape indicators should meet the following criteria (Bjørk et al., 2009):

1 - they should be intuitive, which means that their definitions should be based on easy-to-understand concepts, such as length, width, perimeter and so on;

2 - they should be properly sensible, so visual contrasts between grains must have an impact on the indicator values;

3 - it should be possible to normalize these indicators to values of between 0 and 1 .

Five indicators which totally or partially meet these criteria were selected, and are defined as follows (Roduit, 2007 with some modifications):

1. Compactness $(C)$ means the relation of the grain area to the area of a circle with a perimeter equal to the grain perimeter and that can be calculated with the following formula:

$$
C=\frac{4 \pi \cdot S}{P^{2}}
$$

where: $S$ - grain area, $P$ - grain perimeter; the compactness of an ideal circle is 1.0 ; the compactness of a square is 0.785 .

\section{Isometry $(I)$ can be expressed as follows:}

$$
I=\frac{W}{L}
$$

where: $W$ - width, $L$ - length of the grain. 
Width means length of the shorter side of a rectangle circumscribed on the grain, whilst length means length of the longer side. This parameter was defined by Roduit (2007) as elongation, however, the term "isometry" seems to be more intuitive: an isometric shape, such as a square or a circle, has $I=1.0$, whilst a rectangle or an ellipse has $0<1<1.0$

3. Ellipticity $(E)$ is defined as follows:

$$
E=\frac{\frac{\pi \cdot L \cdot W}{4}-S}{S}
$$

where: $S$ - grain area, $L$ and $W$ - length and width defined as above.

Ellipticity may have negative values. The ellipticity of a circle, as well as that of any other ellipse, is 0 . The ellipticity of a square is 0.56 .

4. Solidity $(S d)$ is the relation between grain area and the area of a convex envelope of the grain:

$$
S d=\frac{S}{S_{C}}
$$

where: $S$ - grain area and $S_{c}$ - area of a convex envelope of the grain.

The convex envelope (convex hull) is the smallest convex polygon that can contain the grain (Bjørk et al., 2009). If the grain has a convex shape then $S=S_{c}(S d=1)$, while in other cases it is always $S_{c}>S(0<S d<1.0)$.

The solidity decreases with increasing area of indents (lobes) in the grain. When the number of indents increases but their total area is constant, solidity is also constant.

5. Convexity $(\mathrm{Cv})$ is a relationship between the perimeter of the convex envelope and the perimeter of the grain, as follows:

$$
C v=\frac{P}{P_{C}}
$$

where: $P$ - grain perimeter, $P_{c}-$ convex envelope perimeter.

In contrast to solidity, convexity is sensible to the number of indents in the grain.

The following statistical parameters were determined: arithmetic, geometric and harmonic means $\left(\mathrm{X}_{\mathrm{A}}, \mathrm{X}_{\mathrm{G}}\right.$, and $\left.\mathrm{X}_{\mathrm{H}}\right)$, median (M), variance (Var), standard deviation $\sigma$, coefficient of variation, skewness (A) and kurtosis (Kurt). The geometrical mean was not determined if in a statistical sample the minimum ellipticity was below 0 . Full statistical data are available as an electronic supplement to this paper (Appendices 1 and $2^{*}$ ).

\section{MICROFABRIC DOMAIN CLASSIFICATION}

The microfabrics of the fault rocks studied in the Western Tatra Mountains show the following characteristic features: (1) the observed fabric and microfabric strongly depends on the observation scale; (2) microfabrics show distinctive variation at a small scale (even of millimetres); (3) coexistence of the completely different microfabric types can occur in one sample.
That complex patterns suggests that microfabric should be described in selected microdomains.

There are two main features which differentiate microfabric types. The first is the presence and abundance of matrix. The following cases are possible: (1) a lack of matrix; (2) a small amount of matrix present mainly in the fractures; (3) there is matrix between grains, but grain-grain contacts are common; (4) grains are completely surrounded by matrix and grain-grain contacts are unlikely.

The second feature is the presence of any preferred orientation in the microfabric, especially any kind of foliation. The following cases were observed in the samples: A - a lack of any preferred orientation (chaotic microfabric); $\mathrm{B}$ - foliation of the matrix (as regards composition and/or grain size); $\mathrm{C}$ - the presence of non-penetrative asymmetrical structures (e.g., rotatated porphyroclasts) and/or foliation of the matrix; $D$ - penetrative asymmetric features (e.g., S-C type of mylonitic foliation) present and (in part) features described in $C$ and $D$.

The combination of these two features gives 16 theoretically possible types of microfabric (Fig. 2). The types distinguished were coded by alphanumeric symbols, where a letter (A-D) describes preferred orientation and a number (1-4) describes the abundance of matrix. Type B1 was not determined, because it has no logical sense (a rock without matrix cannot have foliated matrix). The same was assumed for the B2 type, because matrix was present only in fractures and generally is not foliated. Characteristics of the 14 microfabric types observed in the rocks analysed are given below.

A1 (Fig. 3A, B, D). These microfabric microdomains are present in leucogranites which were not deformed or were just weakly deformed. Typically, A1 microfabrics gradually change into A2 type microfabrics. The A1 type of microfabric is less fractured than the A2 type, probably due to a higher quartz content - this mineral plastically accommodates most of the stress field.

A2 (Fig. 3A, D). This type of microfabric is the most common in the fault rocks analysed. It can be linked with relay zones (Childs et al., 2009), located far from the fault cores. In most cases A2 type microfabrics alternate with A1 type microfabrics. In some cases A2 microfabrics form thicker layers. The sericite matrix in the A2 type of microfabric develops mainly at the contacts between feldspar grains. Feldspars are deformed in a brittle or brittle-ductile regime (Williams et al., 2000; Passchier and Trouw, 2005). Quartz at some locations underwent subgrain rotation (Halfpenny et al., 2006), forming aggregates of elongated subgrains.

The protolith of the fault rocks with A2 microfabrics in most cases was granodiorite, what as shown by microscopic observations.

A3 (Fig. 3C). This type of microfabric is characterized by a matrix/grain ratio about $1: 1$. These microfabrics are formed by mesocataclasites, but generally these are relatively narrow zones between other types, as shown in Figure 3C. In some cases A3 microfabrics gradually changes to A4 microfabrics.

A4 (Fig. 3D). This microfabric type is characteristic of mesoand ultracataclasites. However, this type is rather uncommon, because most of the cataclasites contain some preferred orientation structures. In Figure 3D A4 microfabrics form narrow bands in the layered cataclasites from the Siwa Przełęcz Pass.

B3. This type of microfabric is also uncommon. For example, in the sample from the Siwa Przełęcz Pass, the layered matrix is composed of quartz-feldspar material, with grains up to $0.1 \mathrm{~mm}$ across, and finer quartz-feldspar-clay material. The matrix forms winding, anastomosing bands between grains.

\footnotetext{
* Supplementary data associated with this article can be found, in the online version, at doi: 10.7306/gq.1129
} 


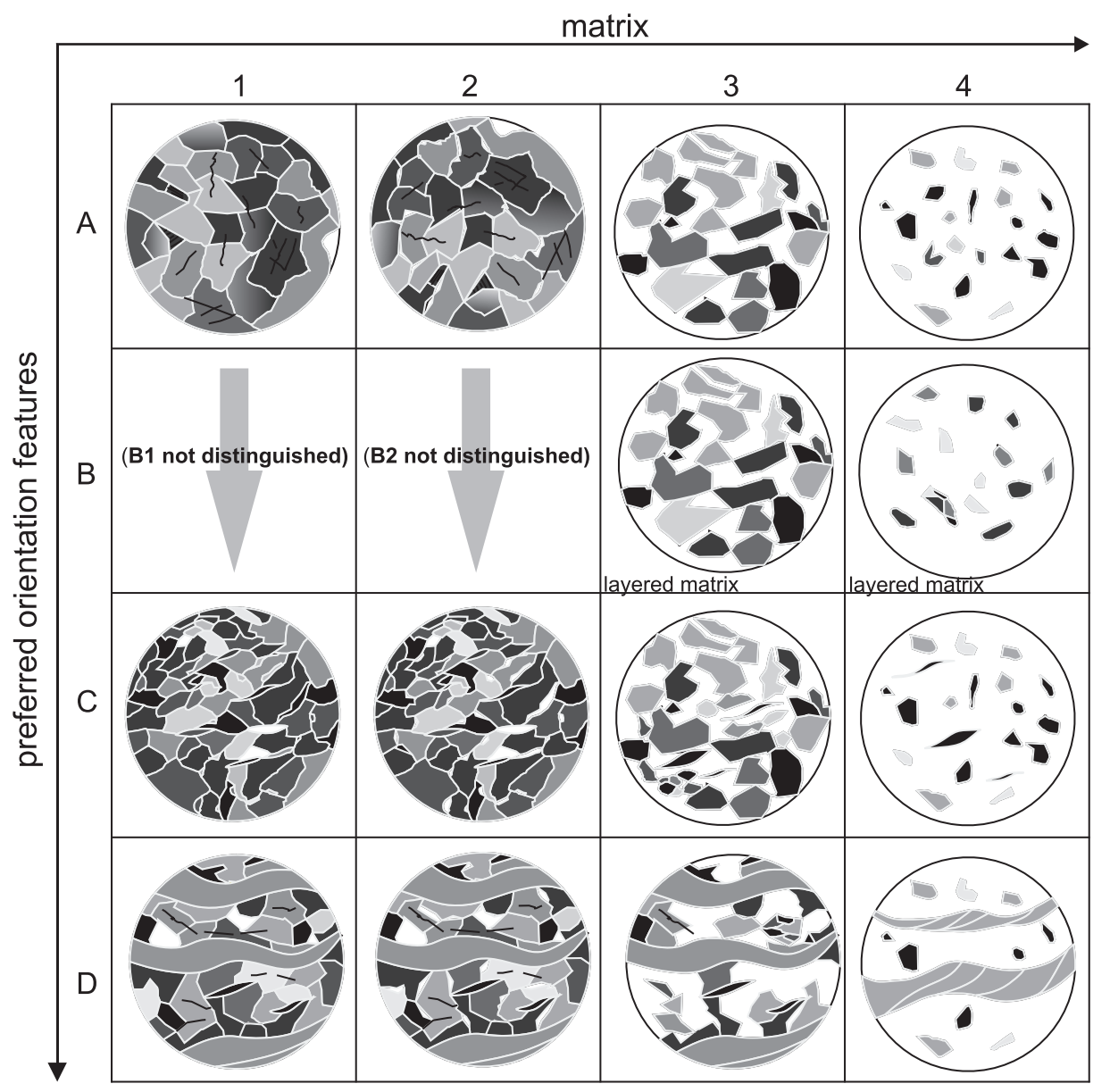

Fig. 2. Microfabric types of the fault rocks distinguished in the Western Tatra Mts.

White background symbolizes matrix; note, the microfabrics in rows $C$ and $D$ contain non-penetrative preferred orientation structures (dextral on this figure); also, note the difference between type 1 and 2 is the presence of a small amount of matrix between grains

B4 (Fig. 3E). This type of microfabric is characterized by a layered matrix and contains various contents of sericite and opaque minerals, including graphite. Layers are up to a few millimetres across, with up $0.5 \mathrm{~mm}$ wide transitional zones in between. Grains are up to $3 \mathrm{~mm}$ across and are composed mainly of quartz, and in places plagioclases. Straight boundaries of the fragmented grains indicate their brittle crushing.

C1. This type of microfabric is uncommon, and limited only to the regions where deformation was ductile, in places overprinted by some later brittle processes. C1 microfabrics are similar to A1 microfabrics, but contain such fabric elements as mica fish or shape-preferred orientation of the grains.

C2 (Fig. 3B). Brittle deformation in these microfabrics is more advanced than in the $\mathrm{C} 1$ type and more matrix is present, not only in fractures but also at grain contacts. This type is uncommon in the samples studied, and occurs mainly in form of bands in the cataclasites.

C3. This microfabric was observed sporadically and is characterized by a 1:1 matrix/grain ratio as well as the presence of mica fish and/or core-mantle rotated porphyroclasts.

C4 (Fig. 3F). This type of microfabric has more matrix than grains. The matrix is composed of sericite or quartz and sericite. Variably shaped and sized $\delta$ or $\sigma$ type porphyroclasts are the preferred orientation feature of these microdomains, as well as bands of white mica up to $0.05 \mathrm{~mm}$ wide and ca. $0.5 \mathrm{~mm}$ long. The rocks with $\mathrm{C} 4$ microfabric are ultramylonites, less frequently S-C cataclasites (Lin, 1999).

D1 (Fig. 3D). This type of microfabric in the most cases forms mica bands with $\mathrm{S}-\mathrm{C}$ type mylonitic formation. Mica bands are often overprinted by later deformation structures. This group embraces phyllonites, some protomylonites and some schists. Rocks with such microfabric occur in zones of intensive brittle-ductile deformation.

D2 (Fig. 3G). This type of microfabric contains grains which are the source of the matrix material. In this group, grains of quartz or feldspars are evenly distributed among bands of micas that are up to $0.2 \mathrm{~mm}$ wide. Locally non-mica phases form layers alternating with mica. The matrix is composed mostly of sericite and occurs in small amounts in the areas where more feldspars are present. The D2 type of microfabric is less abundant than the D1 type, however, it also occurs in the intensive brittle-ductile deformation zones.

D3 (Fig. 3A). This microfabric is composed of alternating layers of grains and of matrix, therefore can be considered as composite of alternating D1 and A3 types of microfabric. In spite 

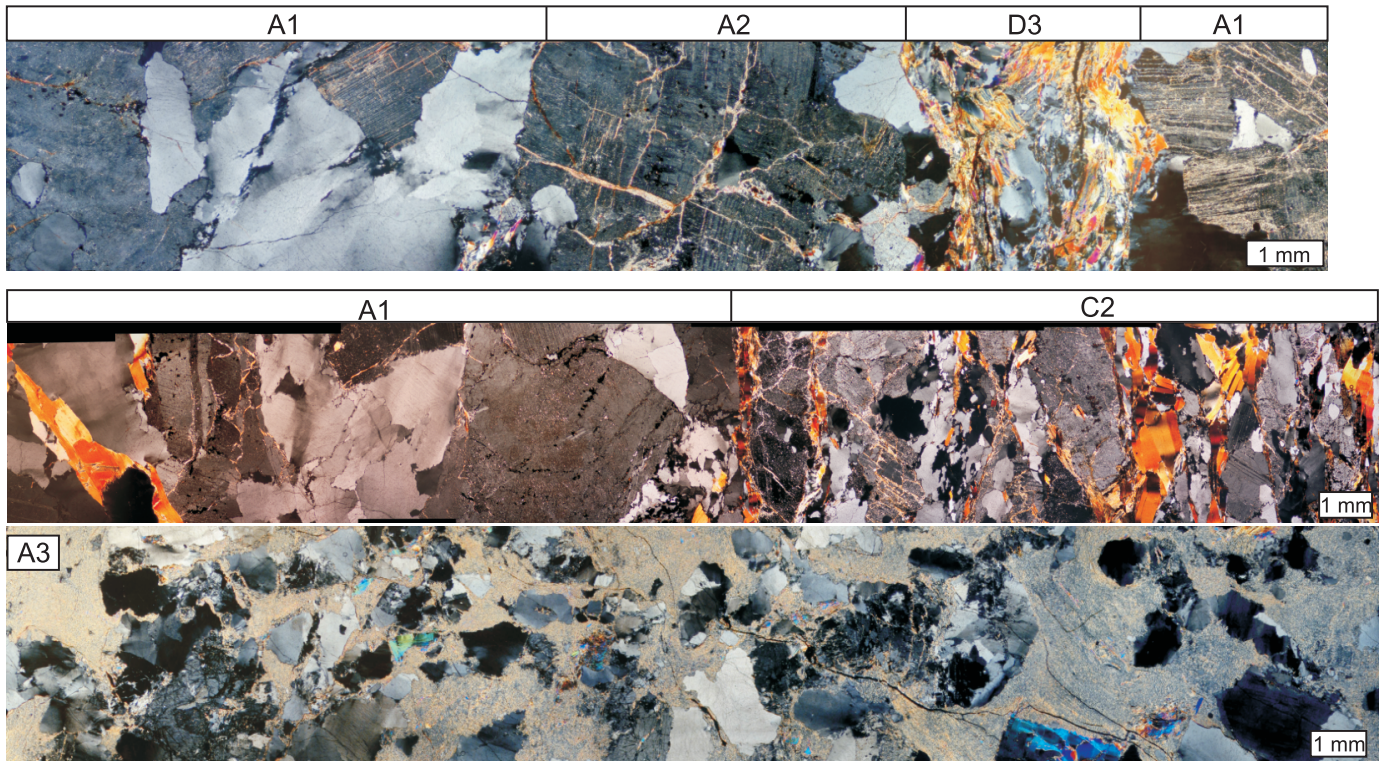

C
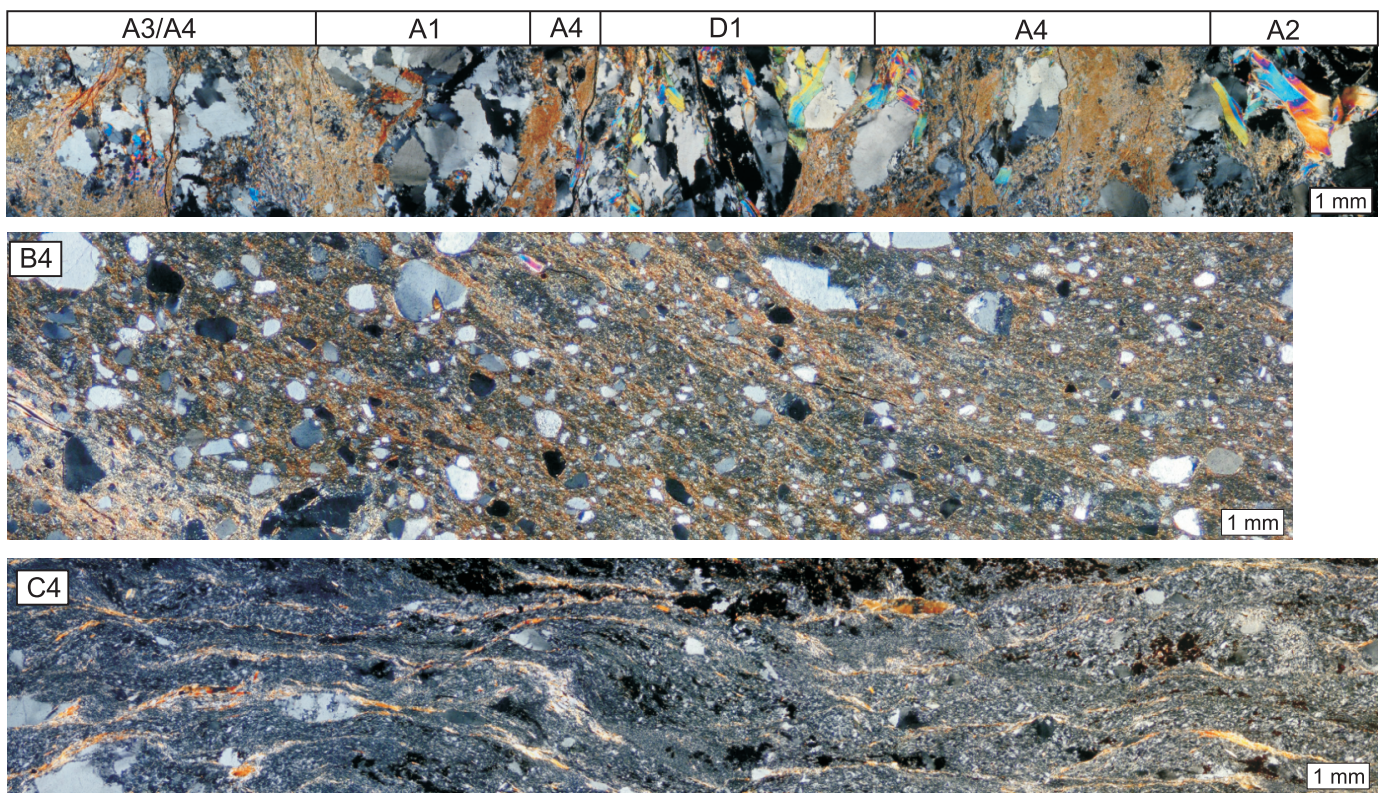

E

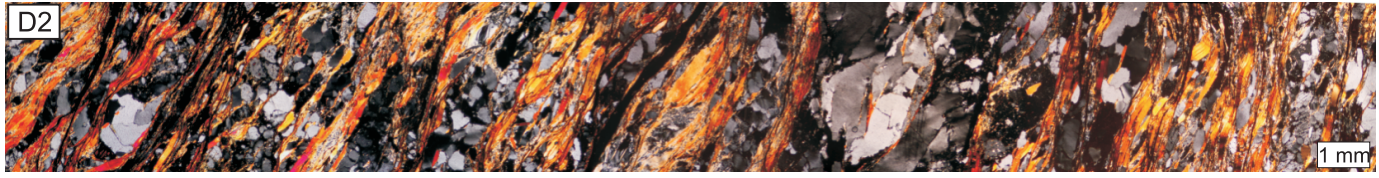

F

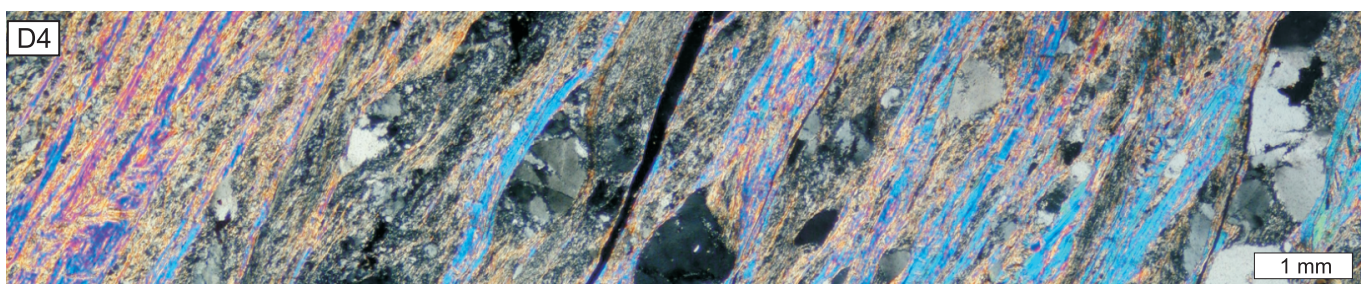

G

Fig. 3. Thin sections (crossed polars) of selected microfabric types: A - Zadni Ornak Mountain; B - Siwa Przełęcz Pass; C - Długi Upłaz Ridge; D - Siwa Przełęcz Pass; E, H - sedlo Zabrat' Pass; F - Wołowiec Mountain; G - Litworowy Żleb

of higher matrix content in the D3 type the features are the same as in the D2 type of microfabric.

D4 (Fig. 3H). This is the last type of microfabrics distinguished, characteristic of ultramylonites with a high matrix content. Clasts resemble these from the B4 type, but mica bands emphasize directional features of the matrix. The matrix com- prises sericite and, especially near to the porphyroclasts, finegrained quartz.

The map showing the main locations of microfabric types (Fig. 1) shows areas with impressive variety of microfabric types, such as in the Siwa Przełęcz Pass and Siwe Turnie areas. Also, different types of microfabrics with weak to intermedi- 
ate intensity of deformation (A1, A2 and $\mathrm{A} 3$ ) predominate in the northern parts of the Western Tatra Mountains crystalline core, whilst to the south, types of microfabric are more varied. Probably this is an effect of the abundance of metamorphic rocks in the southern part of the Western Tatra Mountains.

\section{SELECTED OCCURRENCES OF FAULT ROCKS IN THE WESTERN TATRA MOUNTAINS}

In the most cases the fault rocks of the Western Tatra Mountains occur in the form of cataclasite and mylonite rock complexes, with various thicknesses (from tens of centimetres to tens of metres). The protholits of the fault rocks are typical of the Western Tatra Mountains lithologies: leucogranites (known also as alaskites; Gawęda, 2001), or the "common Tatra granites" (granodiorites to granites; Kohút and Janák, 1994), as well as contacts between igneous and metamorphic rocks.

The fault rocks are mainly exposed in landslide niches, source areas of creeks, as well as in upper areas of the mountain massifs, above the mountain pine cover. Smaller exposures can be found in depressions along the mountain ridge tops (the "double ridges").

\section{DŁUGI UPŁAZ RIDGE}

On Łuczniańska Przełęcz Pass (Slovak - Lúčne sedlo) the fault rocks form five bands, a few metres thick, that alternate with undeformed rocks. Shear zones are developed in leucogranites and gneissic leucogranites with weak magmatic foliation - microfabric type A1. These leucogranites occasionally form bands a few centimetres thick of cataclasites - microfabric type A2 or A3. To the SE, in the Czoło area, granodiorites with protocataclasis traces are also present. These rocks were recognized as Roháče type biotite granites (Gawęda, 2001). The most deformed rocks are protomylonitic schists that alternate with protomylonitic leucogranites - microfabric types C1, C2 and D1, locally, where there is a higher ratio of matrix, also C3.

In the structural interpretation by Cymerman (2009a), fault rocks in this area occupy the boundary between two thrust sheets: the upper Czoło thrust sheet and the lower Dolińczański Żleb couloir thrust sheet.

Fault rocks occurring in the Litworowy Żleb couloir form a complex that outcrops downhill over a distance of ca. $100 \mathrm{~m}$. The intensity of non-coaxial deformation increases downwards. On the Długi Upłaz Ridge above the Litworowy Żleb couloir protocataclasites and mesocataclasties occur. Locally, between these rocks decimetre-thick bands of phyllonites are present, as well as cataclasites of A3 and A4 microfabric type.

The central part of the Litworowy Żleb couloir fault rock complex (Fig. 4A) comprises a heterogeneous sequence of mesoand ultracataclasites, without any visible foliation, (microfabric type A4), as well as S-C cataclasites and mylonites (C4 microfabric type). Even where the rock shows no microfabric foliation numerous brittle shears can be observed. In the lowest part of this complex, mylonitic schists and phyllonites occur together, forming C3 and D3 microfabric type alternations.

Overall, the fault rock complex of the Litworowy Żleb couloir can be recognized as an almost horizontal brittle-ductile shear zone, with ultracataclasites, mylonites and phyllonites in the core, and protocataclasites in the outer part of this damage zone.
The sense of shearing documented by ductile structures (S-C mylonitic foliation and C' shear bands) generally show a top-to-the-NE direction (Fig. 4B). The mesofault record is generally top-to-the-SE and SSW shear sense (Fig. 4C).

Occurrences of brittle deformed leucogranites (A1 and A2 microfabric types) continue towards Rakoń, where augen gneisses and lit-par-lit migmatites dominate (Cymerman, 2009a).

\section{ZABRATY RIDGE}

The Zabraty Ridge, located between Rakon and the sedlo Zabrat' Pass, in its upper part is characterized by brittle and brittle-ductile non-coaxial deformations of gneiss and quartz- or mica-rich schists. In the tectonic interpretation by Cymerman (2009a), this zone is located between a structurally higher gneiss complex (which forms the top of Rakoń), and a lower complex built of leucogranites. The geological map compiled by Nemčok et al. (1994) also shows partially gneissic leucogranites there, with several bands of mylonite.

Various fault rocks of the Zabraty Ridge are represented by proto- and mesocataclasites with A2, A3 and B3 types of microfabric; $\mathrm{S}-\mathrm{C}$ cataclasites ( $\mathrm{C} 2$ and $\mathrm{C} 3$ microfabric type) as well as meso- and ultramylonites (D2 and D3 types of microfabric). The intensity of tectonic deformation and predominance of ductile deformed rocks increase westwards (towards the sedlo Zabrat' Pass). Fault rocks observed on the sedlo Zabrat' Pass are very heterogeneous and comprise meso- and ultramylonites and cataclasites, as well as phyllonites.

\section{WOŁOWIEC MOUNTAIN AND DZIURAWE RIDGE}

On the Wołowiec Massif several zones of fault rock exposures can be distinguished: the northern slopes and peak of the mountain, the western and southwestern slopes, and the southern slopes with the Dziurawe Ridge and the Dziurawa Przełęcz Pass. The upper part of the Wołowiec is composed of granitic gneisses, whilst on the top gneisses are also present (Michalik and Guzik, 1959a). Beneath the metamorphic complex, leucogranites with rare thin amphibolite bands occur.

A wide zone of tectonic mylonitisation was mapped on Wołowiec by Skupiński (1975). Cymerman (2011a) interpreted such damage zones as an effect of non-coaxial deformation in almost horizontal or sub-horizontal planes.

On the northern slopes of Wołowiec, protocataclasites (A2 microfabric) mainly occur, as well as biotite-rich mesocataclasites and granitic gneisses. Gawęda (2001) includes this area (above the leucogranites) to an upper structural unit.

At the top of Wołowiec, in the "double-ridge" depressions, protocataclasites with a leucogranitic protholite occur.

There are numerous outcrops of fault rocks on the NW and W slopes of Wołowiec. At least four zones of moderately cataclased granodiorites and cataclasites can be observed there with some narrow bands of mylonite and phyllonite $(C$ and $D$ group types). Along the tourist paths, at an altitude of ca. $1950 \mathrm{~m}$ a.s.I. a well-exposed complex of fault rocks composed of cataclasites with four narrow, decimetre-scale, bands of mylonite and phyllonite occur. The intensity of non-coaxial deformation increases towards the Jamnícke sedlo Pass (southwards).

Cataclasites are mainly developed in the granodiorites (Roháče type granodiorites - Nemčok et al., 1994). Mesocataclasites are the dominant type of fault rocks. In some loca- 

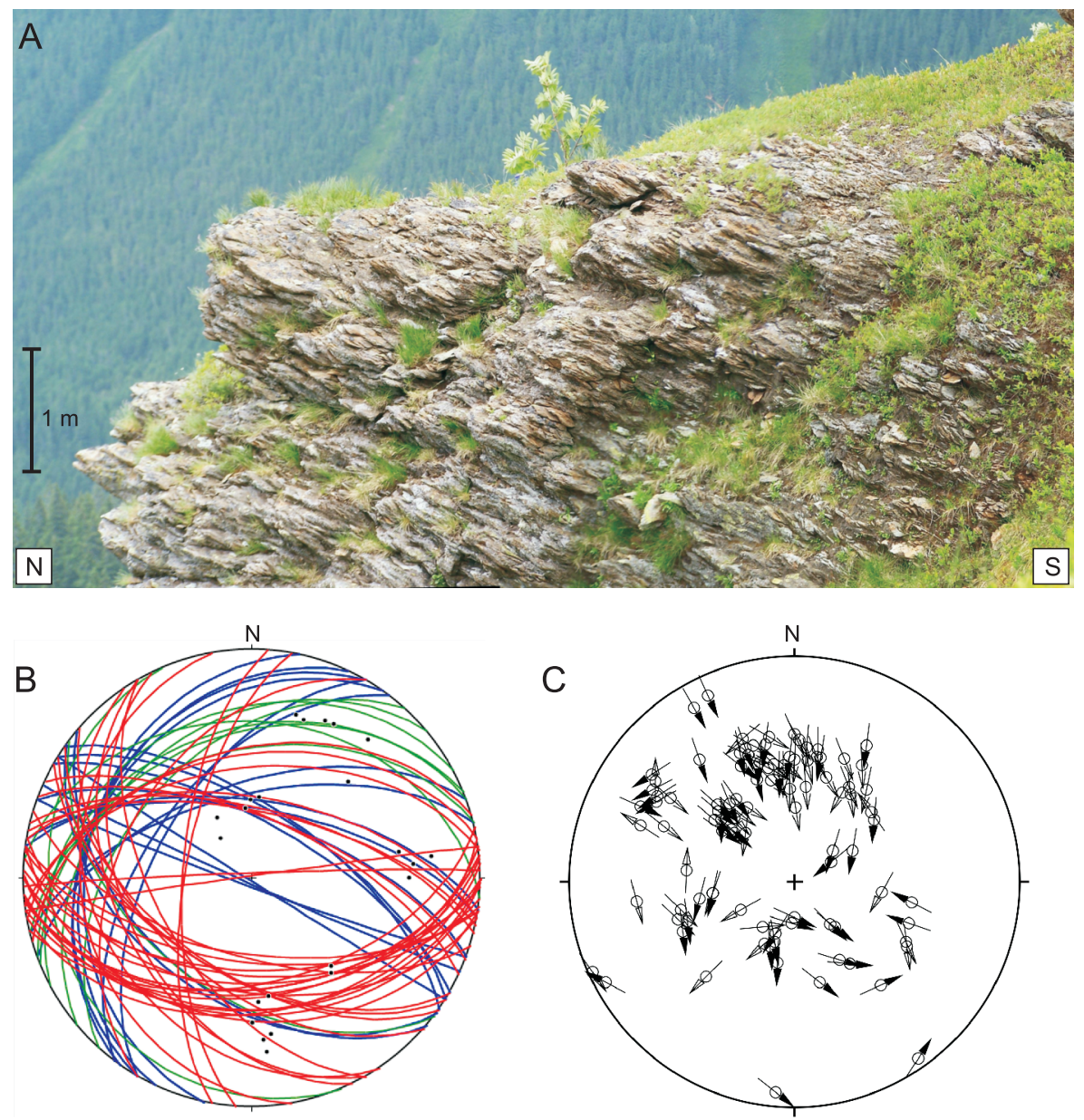

Fig. 4A - examples of ultracataclasites and mylonites at Litworowy Żleb, which is one of the most distinctive fault rock exposures in the Polish Western Tatra Mountains; numerous types of mesofaults such $\mathrm{Y}, \mathrm{P}$ and $\mathrm{R}$ shear planes can be observed; B - structural diagram of mylonitic rocks at Litworowy Żleb; red arcs - S planes, blue arcs - C planes, green arcs - C' shear bands, points - mineral grain lineations; C - Hoeppner plot of the mesofaults at Litworowy Żleb - poles to fault planes, arrows show sense of shearing; both structural diagrams: equal area projection, lower hemisphere

tions ultracataclasites with higher degree of grain reduction are prevalent. The microfabric types of these rocks are $\mathrm{A} 3$ and $\mathrm{A} 4$, less often B3 and B4. Locally cataclastic breccias or fault gouges are present.

This fault rock complex is exposed in several places on the western slopes of Wołowiec, forming the core of a wide, almost horizontal thrust zone at the base of the Wołowiec overthrust recognized and mapped by Cymerman (2009a, 2011a). The gradient of non-coaxial deformation intensity is generally perpendicular to this regional zone of displacement, and increases downwards from the top of Wołowiec. Therefore, this gradation represents an increase in damage effects towards the Wołowiec overthrust. The brittle structures document a top-tothe-S dominating shear sense, whilst mylonitic $S-C$ foliation records generally northwards shearing directions.

On the southern slopes of Wołowiec, there is sharp ridge, called "Grzadki". This ridge is composed of granitic gneisses with numerous, transverse bands of gneiss, granodiorite and amphibolite (Michalik and Guzik, 1959a). According to Gawęda (2001), a mylonitic band between the upper structural unit and adjacent alaskites continues from there towards the Trzydniowiański Wierch Mountain to the NE.

In this area, slightly below an altitude of ca. $1900 \mathrm{~m}$ a.s.l., shear zones with different types of fault rocks occur. Sericite-, biotite- and epidote-quartz schists, often with graphite, occur mainly along depressions in the ridge. According to the field classification of the fault rocks (Brodie et al., 2007), these are mainly mylonites and phyllonites with a dominant D1 (but also C group) microfabric type. This zone can be linked with the marginal area of the Wołowiec overthrust.

Generally, the entire Wołowiec Mountain massif above ca. $1800 \mathrm{~m}$ a.s.l. (the upper wall of the Wołowiec overthrust) can be considered as strongly heterogeneous complex of fault rocks, formed during brittle and brittle-ductile deformation, especially thrusting. This is consistent with the structural model proposed by Cymerman (2011a).

\section{TRZYDNIOWIAŃSKI WIERCH, CZUBIK AND KOŃCZYSTY WIERCH MOUNTAINS}

Trzydniowiański Wierch in its upper part is composed of two complexes of leucogranites, subdivided by a narrow zone of gneisses (Michalik and Guzik, 1959a). A similar interpretation was given by Skupiński (1975), who mapped a horizontal "greisenized tectonic zone" surrounded by pegmatitic leucogranites. According to Gawęda (2001), the topmost part of 
Trzydniowiański Wierch should be considered as belonging to the upper structural unit.

On the western slopes of Trzydniowiański Wierch, outcrops of the shear zones are not easily accessible, due to the thick mountain pine cover, but in the rock scree on the tourist path fragments of different fault rocks can be observed. These fragments suggest alternations of cataclasites, leucocratic granitic gneisses and leucogranites. Michalik and Guzik (1959a), mapped three bands of epidote-chlorite schist and graphite schist here. However, graphite is present also in the other rock types, not only in the schists.

Due to a lack of good exposure, the exact number and position of shear zones cannot be determined in this area. Most of the visible fragments are deformed leucogranites. The intensity of non-coaxial deformation increases upwards, from breccias to cataclasites. Breccias gradually change into protocataclasites: the microfabric changes from $\mathrm{A} 1$ to $\mathrm{A} 2$ and $\mathrm{A} 3$ microfabric types, with features of block-controlled cataclastic flow (Ismat and Mitra, 2005). Cataclased leucogranites occur also to the north of the top of Trzydniowiański Wierch; however, exposures of them are small, mainly located along narrow mountain outcrops.

The data collected allows consideration of the fault rocks of Trzydniowiański Wierch as products of low-angle thrusting of leucogranites over probable earlier ductilly deformed granitic gneisses, which accommodated most of the tectonic stress. The ovethrusted leucogranites were only slightly deformed in brittle conditions with generally top-to-the-SE and SSW shear sense.

The structures described continue to the south. The top parts of Czubik Mountain are composed of granitic gneisses; below these are granitic gneisses in which several shear zones are present (Michalik and Guzik, 1959a). Gawęda (2001) includes these metamorphic rocks into an upper structural unit. According to Cymerman (2011), the southern part of Czubik-Kończysty Wierch Ridge is built of two complexes made up of of small-scale thrust sheets.

Beneath the summit of Czubik, along the tourist paths, cataclased granitic gneisses as well as granodiorites are present. On the western slopes 10-20 cm thick bands of mylonite or mylonitic schist with graphite were also found (C2 microfabric type).

The intensity of non-coaxial deformation along the CzubikKończysty Wierch Mountain ridge decreases to the south. On the northern slopes of Kończysty Wierch, tectonic breccia domains without distinct borders were noted. These are mainly chaotic or fracture breccias without matrix (A2 microfabric type). Protocataclasites (A1 microfabric type) were observed on the southern slopes of Kończysty Wierch.

\section{ORNAK AND SIWE TURNIE RIDGES}

The Ornak Ridge is more than one kilometre long and in its upper part is composed of leucogranites cut by numerous, longitudinal gneissic bands. According to Jaroszewski (1965), the northern part of the ridge is composed of a gneissic complex, and in the topmost parts (Ornak Mountain) there is a granitic complex. Migmatic gneisses and mylonitic greisens to the south of the Siwa Przełęcz Pass were mapped by Skupiński (1975). Gaweeda (2001) showed alaskites to the north, and upper structural unit rocks to the south.

Generally, in the metamorphic rocks of this ridge shear zones are very difficult to interpretation, but, especially microscopically, effects of brittle reactivation of older, ductile structures are sometimes visible. Breccias (A2 or A3 microfabric type) are observed in the southern vicinity of Ornaczańska Przełęcz Pass. Further to the south in the area of Zadni Ornak
Mountain, breccias gradually change into leucogranitic protoand mesocataclasites. On the southern slopes of Zadni Ornak $10-20 \mathrm{~cm}$ wide bands of mylonitisation with D group microfabric are present.

The observed mesofaults show a dominant top-to-the-S shear sense, and mylonitic S-C structures document a top-tothe WNW direction.

To the south, the area of the Siwa Przełecz Pass is strongly heterogeneous with proto- and mesocataclasites present. B2 and B3 type S-C cataclasites and mylonites were also noted. Fault rocks form bands up to tens of $\mathrm{cm}$ thick between almost undeformed leucogranites.

In some domains, especially in the vicinity of Kotłowa Czubka Mountain, cataclasites with advanced grain reduction (C2 microfabric) coexist with bands of schist (C3 microfabric) with D3 ultramylonitic laminae.

Siwe Turnie forms a narrow, rocky ridge between the main Western Tatra Ridge (Polish-Slovakia border), and the Siwa Przelęcz Pass with the Ornak Ridge. This ridge is composed of granodiorites (Michalik and Guzik, 1959b) with epidote-chlorite rocks and graphite schists. Jaroszewski (1965) included these rocks into a gneissic complex with some outcrops of a granitic complex, and Gawęda (2001) suggested the existence of an upper structural unit with bands of amphibolite and mylonite, as well as, sporadic outcrops of alaskite.

In the Siwe Turnie rocks characteristic features are alternations and strong non-coaxial deformation of the rocks deformed under brittle to ductile conditions, representing $\mathrm{C}$ and $\mathrm{D}$ microfabric types. Ductile deformed rocks begin to predominate southwards (gneisses and granitic gneisses with features of mylonitization).

\section{KOPA KONDRACKA MOUNTAIN-GORYCZKOWE CZUBY RIDGE}

The last region analysed is located in the eastern part of the Western Tatra Mountains where Michalik (1958) mapped gneisses below leucogranites. Gawęda (2001) recorded there alaskites also. The ridge from the Kopa Kondracka Mountain to the Kondratowa Przełęcz Pass is composed of various metamorphic rocks, with non-coaxial deformation features and various microfabric types showing gradual changes between mesomylonitic gneisses and ultramylonitic or phyllonitic bands about $1-2 \mathrm{~cm}$ wide. Gneisses locally show blastomylonitc features and mylonitic foliation documenting a topto-the NW shear sense.

Cymerman (2009b) described three, imbricated, crystalline thrust sheets in this area. The base of one of these units (the Wielkie Szerokie thrust sheet) comprises a heterogeneous shear zone, composed of proto- and mesocataclasites, fracture breccias and thin bands of phyllonites.

The gneisses of Kopa Kondracka show weak traces of the brittle deformation documenting a top-to-the-SSW shear sense.

The Suchy Wierch Kondracki Mountain is composed of a schist and gneiss complex, with a sedimentary protolith as recognized by Burchart (1970). These rocks show numerous features of ductile deformation (especially mylonitic foliation). The intensity of these features increase to the east, where narrow zones of breccia, cataclasite and a thin band of phyllonites also occur. The fault rocks represent microfabric of all four groups (A-D types of microfabric).

In the Suchy Wierch Goryczkowy vicinity fault rocks form several complexes, metres thick, composed of granitic mesocataclasites and phyllonites, some tectonic breccias and sporadically a few millimetres wide bands of pseudotachylyte. 


\section{GRAIN SHAPE ANALYSIS RESULTS}

\section{COMPACTNESS}

The first section of Appendix 1 shows selected statistical data of the compactness in the selected samples. For the leucogranites (A1 microfabric type), which are protoliths of the most of the fault rocks, compactness has relatively small values with means of $0.52-0.58$. Distribution of the values is polymodal (Fig. 5), peak values representing different mineral phases: the quartz grains have the smallest values, elongated, straightsided, feldspars have intermediate values, while isometric feldspars have the highest values.

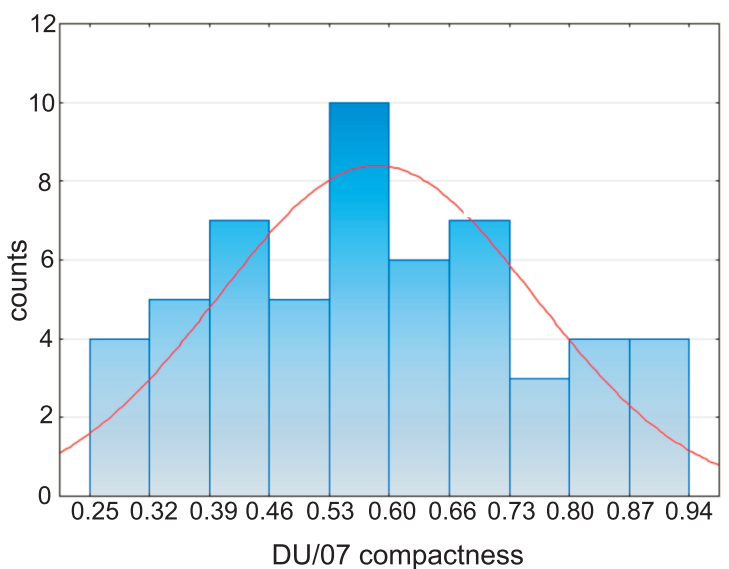

\section{ISOMETRICS}

The second section of Appendix 1 contains selected statistical data of the isometrics parameter. The characteristic feature is strongly positive skewness in the mylonites. This can be an effect of elongation of the grains during dynamic deformation, especially by pressure solution processes. The original elongation of the grains has little influence on the isometrics parameter in mylonites. In the ultracataclasites from nearby locations and, probably, of the similar genesis (sample ZA/01), the mean value is 0.67 and the skewness is negative $(-0.18)$, which means that generally isometric grains dominate.

Strongly elongated grains can be formed also in cataclasites during quartz recrystallisation. These grains form

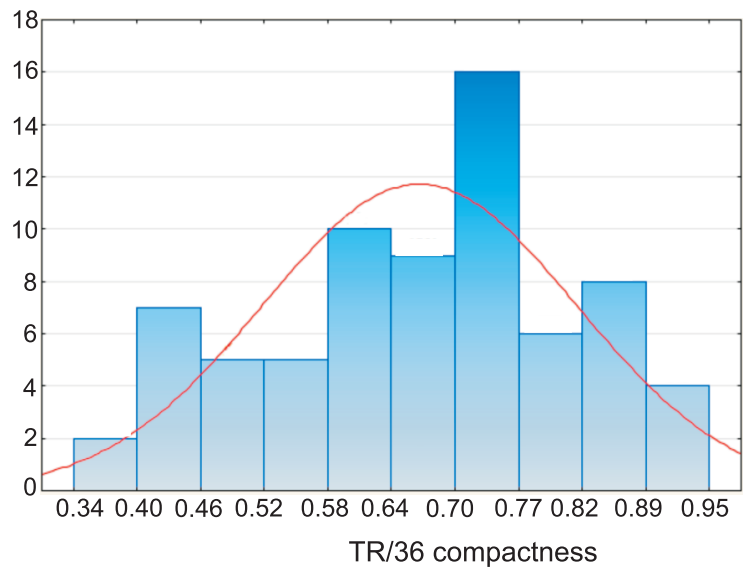

Fig. 5. Compactness distribution histograms for the samples DU/7 (left) from Długi Upłaz Ridge and TR/36 (right) from the Trzydniowiański Wierch Mountain

The beginning of deformation in brittle conditions causes increase of the compactness values. For the cataclastic breccias, with A2 microfabric type, mean values are between 0.55 and 0.60 and even more for $\mathrm{A} 2$ microfabric type of protocataclasites (0.63-0.69). The median is also shifted to the right. The distribution is unimodal, and the skewness is negative. S-C cataclasites show higher compactness than non-deformed or weakly deformed rocks.

Progress of cataclasis causes a weak values increase in compactness. In Figure 6 this tendency is shown as median values of compactness arranged with increasing degree of brittle deformation. The highest compactness was observed in the mesocataclasite OR/43 with A2 microfabric type. For the cataclasites which include any foliation feature (S-C cataclasites or cataclasites with microfabrics of the $\mathrm{C}$ group), the compactness medians are lower than in cataclasites with microfabrics of group A.

Comparison of the compactness distribution for rocks with intermediate degrees of deformation (sample OR/43), and a high degree of deformation (sample ZA/01), where both of the samples have a layered matrix (B3 and B4 microfabric types), show, that further progress of cataclasis does not change compactness.

For the mylonites, similar relationships between the degree of deformation and compactness can be barely observed. This is probably due to recrystallisation modifying values achieved during brittle deformation.

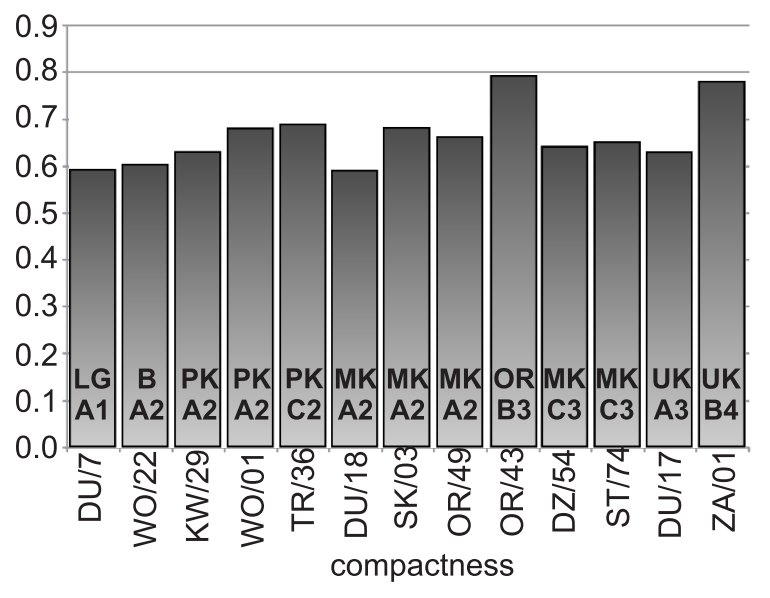

Fig. 6. Comparison for the compactness medians

LG - leucogranites, B - cataclastic breccias, PK - protocataclasites, MK - mesocataclasites, UK - ultracataclasites. Microfabric types are also shown, as well as, sample names with general location codes (DU - Długi Upłaz Ridge, WO - Wołowiec Mountain, KW - Kończysty Wierch Mountain, TR - Trzydniowiański Wierch Mountain, SK Suchy Wierch Kondracki Mountain, ZA - Zabrat Ridge, OR - Ornak Ridge) 
quartz ribbons typical of the SGR process (sub-grain rotation; Passchier and Trouw, 2005). Such structures can be disintegrated (e.g., by brittle reactivation of the originally ductile shear zone). In spite of the scattering of these grains in the matrix, they conserve their elongation. This can explain low values of the isometrics parameter (which means a high dimensional contrast) for some of the cataclasites - samples DU/18 and OR/43 (Fig. 7). Sample OR/43, despite layering in the matrix, is mesocataclasite, with an elongation median of 0.62. Similar values were observed for other mesocataclasites. The median of sample DU/18 is 0.5 . A lower value is an effect of elongated grains present. Microscope observations show that most of the elongated grains are quartz.

\section{ELLIPTICITY}

Selected statistical data of ellipticity are given in the last section of Appendix 1. The relationships between ellipticity and microfabric turn out to be rather weak. The highest mean values are observed for the weakly deformed rocks: leucogranites (XA $=0.38$ ). In some of the mesocataclasites (sample OR/43), ultracataclasites (sample ZA/01) and ultramylonites (sample ZA/02) mean values are low (respectively: $0.13,0.17$ and 0.21 ). Low ellipticity means that grain shapes differ from an ideal circle or ellipse, but does not imply elongation of the grain. Moreover, ellipticity may have negative values. Therefore ellipticity is not the best grain shape indicator.

\section{SOLIDITY}

Solidity and convexity are probably the best grain shape indicators. The first section of Appendix 2 gives some descriptive statistics of the solidity.

Solidity distributions can be divided into three groups. The first group shows flat, bimodal distributions with a minimum between peaks at about 0.90 . The second group shows a sharp, unimodal distribution with a maximum at about 0.91. The third group has unimodal distributions with negative skewness and a maximum at about 0.96 .

The first group comprises fault rocks with weak or intermediate degrees of tectonic deformation, such as initially deformed leucogranites, protocataclasites and mesocataclasites. For these rocks, the solidity distribution is generally flat, which is expressed by the low kurtosis value, e.g. -0.31 in sample DU/07 (Fig. 8). Distribution is mainly influenced by following factors: (1) presence of hypidiomorphic feldspars, which implies higher solidity values, (2) the presence of xenomorphic quartz, (3) protoclastic texture with complicated grain boundaries, numer-
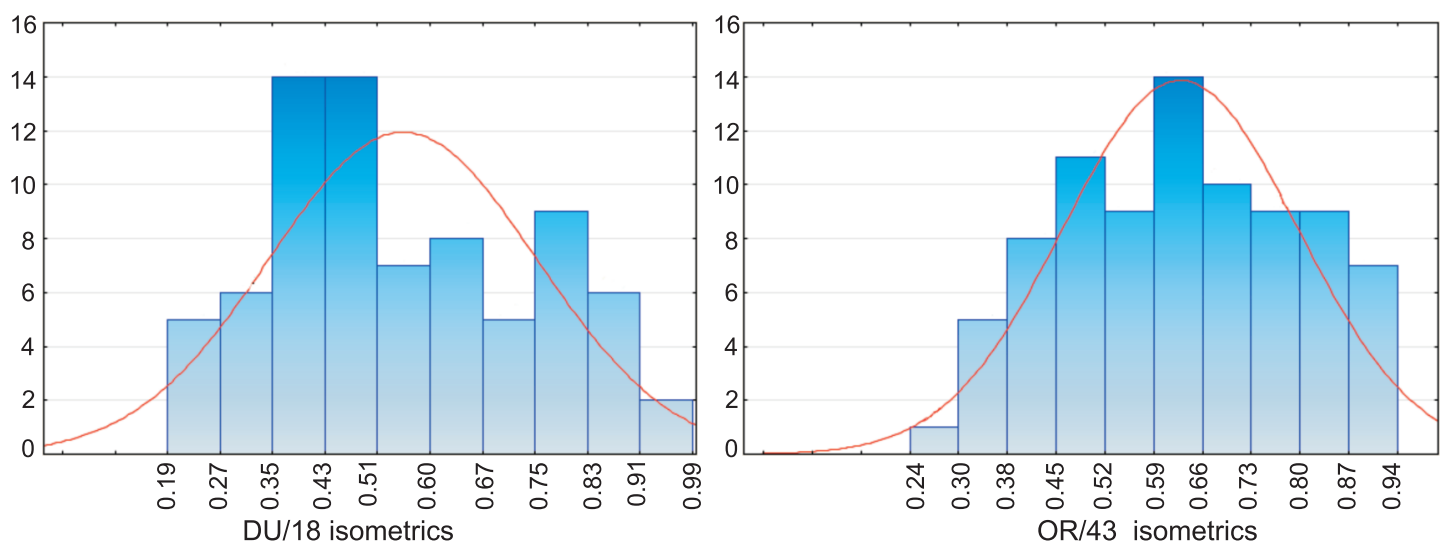

Fig. 7. Isometrics distribution diagram for the samples DU/18 (left) from Długi Upłaz Ridge and OR/43 from Zadni Ornak Mountain
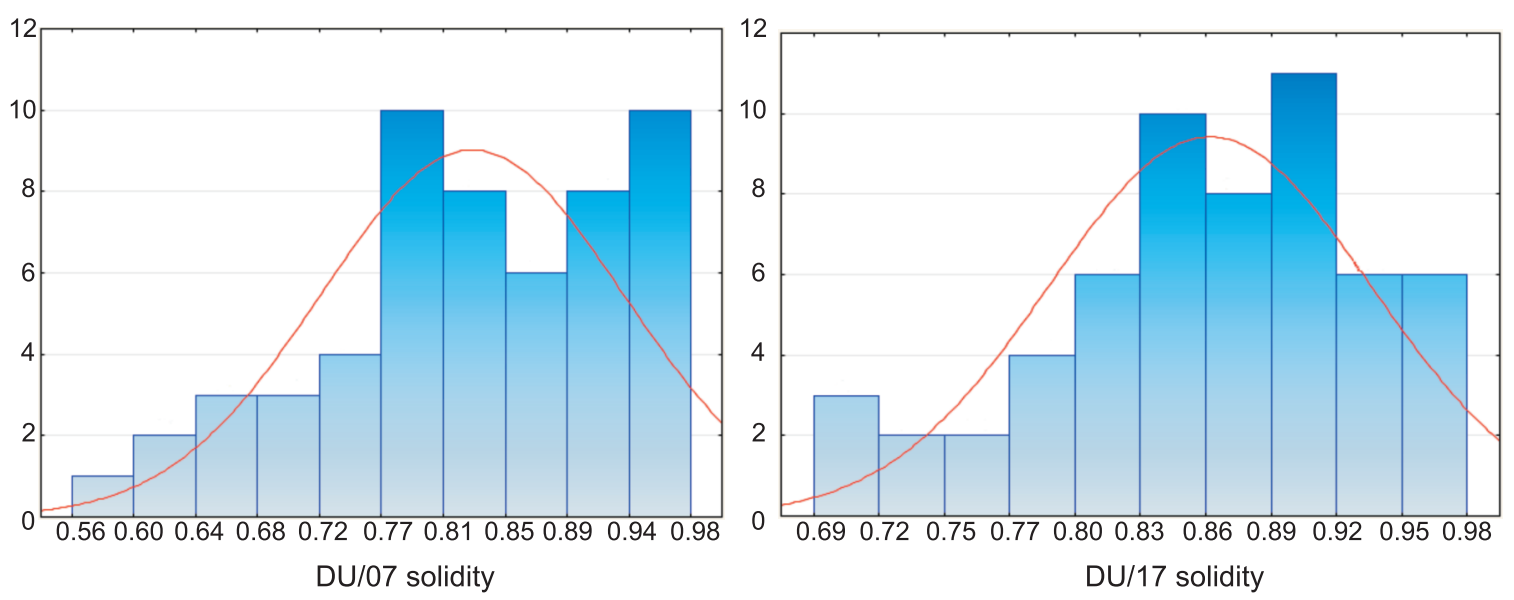

Fig. 8. Solidity distribution histograms for the samples DU/07 (left) and DU/17 (right) from Długi Upłaz Ridge 
ous indents, and magmatic corrosion lobes implies extension of the distribution to the left. The effect of the interaction of these three factors is a bimodal distribution with low kurtosis.

Progressive deformation in brittle conditions results in an increasing number of straight grain borders, which is induced by fracturing grains along some preferred planes. This leads to increase of the kurtosis distribution - in cataclastic breccias to 1.25. More distinctive negative skewness is also observed: -0.7 , and -0.4 in leucogranites.

Distributions of solidity for proto- and mesocataclasites are usually similar: negative skewness, and maximum values of $0.8-0.9$.

In the rocks with a greater intensity of deformation kurtosis rises up to 1.6-1.9, the maximum value is shifted to values above 0.9 and the distribution is strongly asymmetrical with skewness up to -1.6. This is true both, for ultracataclasites and ultramylonites.

The ultracataclasite from Długi Upłaz (DU/17; Fig. 8) differs from the scheme described above. Distribution of the solidity is similar to that observed in leucogranites: flat kurtosis -0.02 , with slightly negative skewness, and a mean value of 0.85 . This can be interpreted as an effect of preservation typical of undeformed leucogranite grain shapes during intense sericitization.

\section{CONVEXITY}

Generally, the distribution of convexity is similar to that of solidity (Appendix 2). Skewness of the convexity is usually negative. Again, irregular grain boundaries in DU/07 leucogranites produce complicated and flat convexity distributions. These features were probably inherited in the ultracataclasite DU/17. On the other hand, rocks with textures developed during long-term cataclastic flow have distributions with a distinctive maximum and high kurtosis

\section{CORRELATIONS BETWEEN GRAIN} SHAPE INDICATORS

Clear correlation is observed for the following pairs: compactness and convexity, compactness and ellipticity, compactness and solidity. In Figure 9, which shows correlation diagrams of convexity versus compactness for two selected samples, the presence of two trends can be noted. The first of these trends is characterized by a decrease in compactness with decreasing solidity. The second is characterized by a stable value (about 1 ) of compactness while solidity decreases. Similar trends are observed for other samples.

The grains of the first trend therefore have increasingly "wrinkled" boundaries, whilst the grains of the second trend do not have very wrinkled boundaries but posess more "amoeboid" shapes. The solidity indicator shows, that depth of grain indents increases too.

The second, stable trend is characteristic of ultracataclasites and ultramylonites with distinctive features of cataclastic flow. That is true for example for the ZA/01 ultracataclasite and ZA/02 ultramylonite, but not for the DU/17 ultracataclasite.

These results suggest that relationships between compactness and convexity should be considered as an important factor in fault rock grain shape analyses. Cataclastic flow processes result in a horizontal, stable trend on $\mathrm{Cv} / \mathrm{C}$ correlation diagrams. A distinctive negative correlation suggests that cataclasite was formed during rapid fracturing and sericitization, without rotation.

\section{PROPOSED MODEL OF THE TEXTURAL EVOLUTION OF THE WESTERN TATRA SHEAR ZONES}

A model of the development of the shear zones should link two facts: (1) the fault rocks are strongly heterogeneous; (2) shear zones were formed during non-coaxial brittle and brittle-ductile deformation processes, as indicated by their microfabrics.

In the following discussion the deformation complex is defined as all fault rocks with a given mineral composition and fabrics, formed during one phase of deformation. These complexes should not be understood as separate phases of deformation.

Deformation began with fracturing of the grains especially along some preferred crystallographic planes. At first, intracrystalline fractures began to form in the plagioclases. Stress was partially accommodated by quartz too, producing undulose extinction. Deformation conditions are below regime I of Hirth and Tullis (1992). During this stage, A1 type fabric gradually changes to A2 type. The irregular grain boundaries that dominate are an effect of syn-magmatic deformation (Vigneresse and Tikoff, 1999). Weakly deformed granitoids take the form of lenses or boudins (DA deformation complex), surrounded by narrow cataclasite - mylonite zones (DB deformation complex). In DA complexes A1 or A2 type microfabrics dominate, whilst in DB complexes A3, B3 and C1 types of microfabric are most
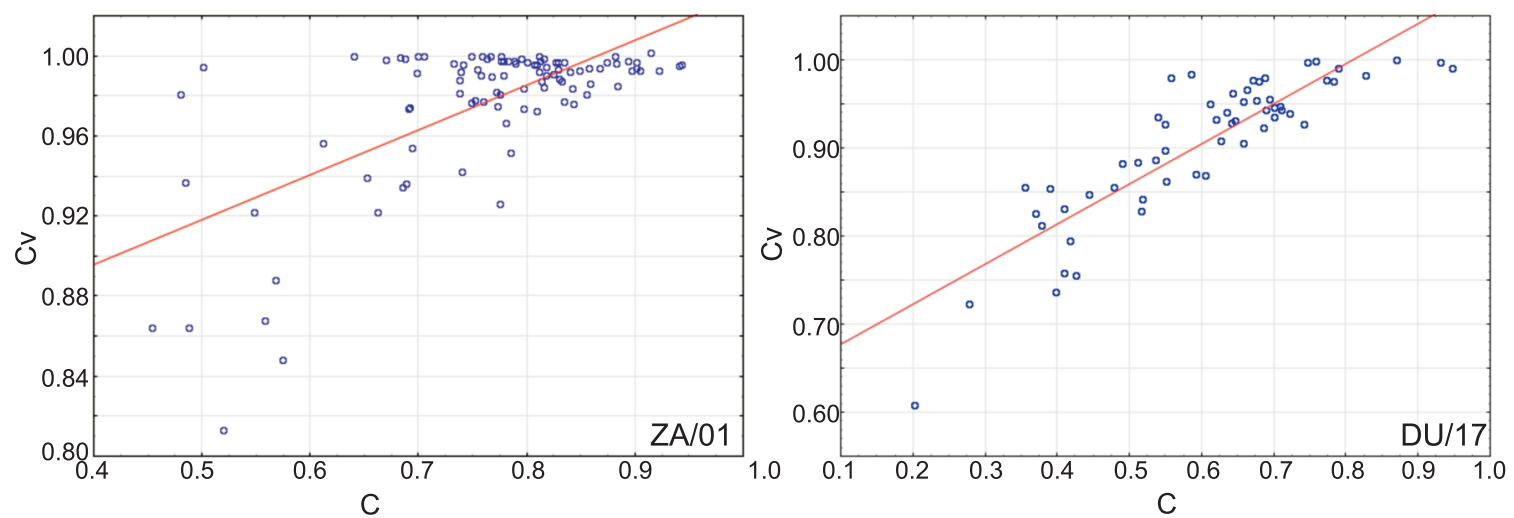

Fig. 9. Correlation diagrams of convexity (Cv) vs. compactness (C) for ultracataclasites ZA/01 from sedlo Zabrat' Pass (left) and DU/17 from Długi Upłaz Ridge (right) 
likely. The differentiation between DA and DB deformation complexes is an effect of strain (deformation) partitioning (Jones and Tanner, 1995; Druguet et al., 2009; Carreras et al., 2013).

With progression of the non-coaxial deformation, transgranular fractures begin to develop. The orientation of these fractures is controlled rather by the shear zone dynamics than by internal grain features, and in consequence structures typical of brittle shearing are formed with a system of $Y(D), P$ and $R$ faults (Katz et al., 2004). There are two main cataclasis mechanisms: fracturing and rotation (Engelder, 1974); at this stage the first one is mainly active. In the DB deformation complexes dynamic recrystallisation by bulging (BLG; Passchier and Trouw, 2005) is active, forming fine-grained quartz aggregates. Temperatures during these processes were less than $400^{\circ} \mathrm{C}$ (Hirth and Tullis, 1992; White, 2001).

With higher matrix contents, the rheology of the rock is different. Thus, rocks with high matrix content are included in the next, DC deformation complex. The rock undergoes softening due to feldspar sericitization, especially when acid fluids are present (Wintsch, 1995; Wibberley, 1999). This reaction releases silica which can be transported and deposited elsewhere, leading to locally hardening of the cataclasites (Wibberley, 1999). In particular, silica can be transported out from the marginal zones of the overthrusts, where the phyllonites are formed (Hippertt, 1998). This may be a mechanism of forming phyllonites on the Dziurawe Ridge, in the basal zone of the Wołowiec overthrust.

Shearing in the DC deformation complex is characterized by pseudo-plastic, matrix-controlled, cataclastic flow (Engelder, 1974; Ismat and Mitra, 2005). Rotation of rigid grains in ductile matrix can lead to subparallel metamorphic layering of the matrix (Wilson et al., 2009). This can explain matrix layering in the B3 and B4 fabric types which are typical of the DC deformation complex.

The DC deformation complex can be subdivided in two subcomplexes, according to the relative abundance of quartz in the matrix: DC-H is harder, cemented by silica, and DC-S is weaker, silica depleted. Hardened, often foliated, cataclasites of the DC-H complex were likely formed in semi-brittle conditions, at depths of ca. 8-10 km and temperatures of ca. 200-250 $\mathrm{C}$ (White, 2001).

The DC-S deformation complex is composed mainly of mica-rich mylonites or phyllonites, which are present mainly on the passes, due to their lower resistance to weathering.

The DD deformation complex comprises strongly recrystallized mylonites or phyllonites. According to the rheological fabric subdivision (Handy, 1990; IWL - interconnected weak layer and LBF - load-bearing framework), two subcomplexes should be distinguished. DD-P represents ultramylonitic phyllonitic complexes, with IWL rheology and D4 type of fabric. DD-M comprises mesomylonitic complexes, with LBF rheology and D2 or D3 microfabrics.

The entire proposed working model is shown in Figure 10. Three main stages can be distinguished:

1 - initiall strain partitioning in brittle conditions, leading to development of the shear zone network (DB deformation complex) and packets of slightly deformed DA deformation complex;

2 - cataclastic flow and sericitization leading to formation of the DC deformation complex. Silica leaching and deposition then forms two deformation subcomplexes: DC-S and DC-H;
3 - Further recrystallization led to the formation of the DD-P and DD-M deformation complexes, mainly due to their fabric and rheology. These processes in general have not exceeded the feldspar plasticity limit - ca. $400^{\circ} \mathrm{C}$ (Passchier and Trouw, 2005).

According, to the concept proposed by Cymerman (2009a, b, 2011a) of the development of a crystalline core structure with numerous overthrusts and thrust sheets, the core parts of these overthrusts and thrust sheets (relay zones, Childs et al., 2009) are composed of DA + DB deformation complexes, whilst the shear zones are generally associated with DC deformation complexes. The marginal zones are composed of the DD-P deformation complex. This can be observed in Wołowiec area, for example, where phyllonites build the Dziurawe Ridge with the Dziurawa Przełęcz Pass in the bottom zone of the Wołowiec overthrust (Fig. 11).

\section{DISCUSSION}

\section{SHEAR ZONES IN THE WESTERN TATRA AND IN THE HIGH TATRA MTS.}

In the Western Tatra Mountains strongly heterogeneous shear zones comprising a wide range of fault rocks occur. The textures of these rocks are an effect of tectonic processes, as well as their pre-tectonic composition and fabric. It is clear that some the fault rocks, especially in the southern part of the crystalline rocks studied, underwent several phases of deformation, at various conditions of pressure, temperature and/or strain rate.

Jurewicz and Bagiński (2005) described shear zones in the High Tatra Mountains and distinguished three phases of non-coaxial deformation: 1 - pre-Alpine, brittle-ductile, leading to mylonitisation; 2 - Alpine, in brittle conditions with phases of shearing and extension; 3 - Paleogene, with shearing and mineralisation. This model assumes only one phase of cataclasis. These authors noted that in the High Tatra Mountains there are two dominating orientations of the shear zones: (a) flat, gently 


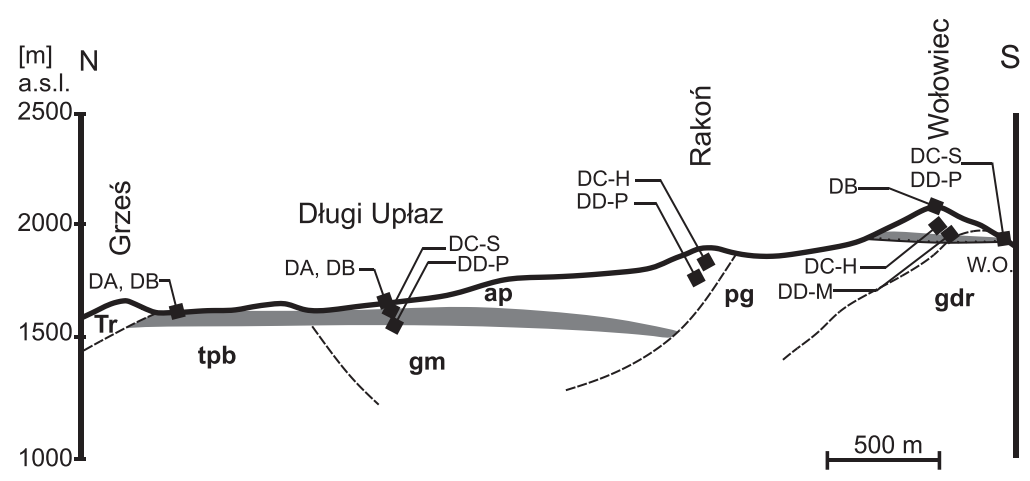

Fig. 11. Schematic geological section of the Western Tatra Mts. between Grześ (Slovak - Lúčna) Mountain and Wołowiec Mountain after Skupiński (1975) simplified

Zones of tectonic greisenisation shown in grey; $\mathrm{Tr}$ - Triassic sedimentary cover, $\mathrm{tpb}$ - plagioclase-biotite tonalites, gm - migmatitic gneisses, ap - leucogranites, pg - pegmatoidal leucogranites, gdr - granodiorites; the following informations are added: position of the Wołowiec overthrust (W.O.) (Cymerman, 2001), and locations of the deformation complexes distinguished; for other explanations see Figure 10

dipping faults, and (b) steep, individual faults, which are interpreted as partially Alpine in age. This situation differs from the Western Tatra Mountains, where I have observed mainly almost horizontal brittle shear zones. However, despite their orientation, these Western Tatra zones resemble the debris zones described by Grochocka-Piotrowska (1970) and the steep dislocations comprising mylonites and/or cataclasites described by Jurewicz (2002).

BRITTLE DEFORMATION

IN THE WESTERN TATRA MOUNTAINS

It seems difficult to find a place in structural model of the two inversed metamorphic units (e.g., Janák, 1992, 1994) for brittle or brittle-ductile deformation. If the shear zones described herein were formed during Late Variscan regional metamorphism (Gawęda and Burda, 2004; Deditius, 2004), there is the question as to why the zones of the intensive shearing lack amphibolite and greenschist metamorphic facies mineral paragenesis (Burchart, 1970; Skupiński, 1975)? On the other hand, Gaweda and Burda (2004) suggested that Alpine deformation could be linked with cooling of the crystalline massif. However, this does not explain the presence of numerous strongly heterogeneous shearing structures, especially when considering their strong non-coaxiality.

In general brittle and brittle-ductile rocks developed under heterogeneous shearing processes are typical of the Western Tatra Mountains crystalline rocks. Deditius (2004) did not pay much attention to the presence of the cataclasites in the area of the Wołowiec, Trzydniowiański and Czubik mountains, and interpreted all mylonites as Variscan in age. It seems that the variety of the Western Tatra tectonites, as well as importance of cataclasites, has been underestimated. Cataclasites in the Western Tatra Mountains are not only a common type of rock, but often - with mylonites - form fault rock complexes up to tens of metres thick as observed at Litworowy Żleb or Wołowiec, but also on the Slovak territory - e.g., on the southern slopes of the Jarząbczy (Slovak Hrubý) Mountain (Cymerman, 2011a).

No less than two phases of shear deformation can be distinguished on the Wołowiec Massif. The older, during ductile condi- tions lead formed mylonitic foliation structures, with apredominant top-to-the-N or NW shear sense and numerous mesofolds with NW vergence (Cymerman, 2009a). The second phase was characterized by a brittle to brittle-ductile style of deformation. Therefore, the products and the structures developed in the younger phase are not only an effect of the palaeostress field, but also of overprinting of the older structures. The coexistence of the ductile and brittle deformation structures indicates an important role of the reactivation of ductile shear zones in brittle conditions. However, it is possible that some of the ductile structures are of younger age.

In the Slovak part of the Western Tatra Mts., Alpine in age deformations, developed under brittle conditions recorded a top-to-the-NW shear sense and are interpreted as a product of Late Cretaceous contraction (Janák et al., 2001). On the other hand, stress palaeotensor reconstruction in the Polish Tatra Mountains in brittle shear zones shows a generally $\mathrm{N}-\mathrm{S}$ oriented $\sigma_{1}$ axis, which is in concordance with the typical European Alpine stress field (Nemčok et al., 1989; Guermani and Pennacchioni, 1998; Jurewicz, 2000; Cymerman, 2011b). This make an Alpine age of the brittle non-coaxial shearing structures very possible, however, their detailed orientation and kinematics can be partially inherited from older, Variscan structures.

GRAINS SHAPE ANALYSIS AND CATACLASTIC FLOW

Grain shape analysis is a principal microstructural tool enabling reconstruction of the cataclastic flow mechanism. Simplicity and low costs are the main advantages of this method. The main disadvantage is that the method is limited to two-dimensional sections.

The results show that compactness, solidity and convexity are the most useful indicators. The most important information which can be obtained is whether the the cataclasis was rapid or slow with cataclastic flow. The former is probably responsible for the dominant horizontal trend in the $\mathrm{C} / \mathrm{CV}$ correlation diagram (Fig. 9, left).

The second question is how progress in non-coaxial deformation impacts on grain shapes. The most brittle-deformed in the cataclastic flow samples show high kurtosis of compactness, between 1.6 and 2.6; maximum compactness above 0.9 and strong positive skewness at about 1.6. The same is true for both ultramylonites and ultracataclasites, and so compactness distribution can be considered as an indicator of rotational deformation. Intense cataclastic flow increases compactness values as well as the kurtosis of its distribution. Weakly deformed rocks show negative kurtosis of compactness.

The new results obtained show that solidity distribution can be an indicator of the degree of deformation. Solidity can be used to measure a parameter which can be named the "textural maturity" of the fault rock. Material subjected to intense cataclastic flow, which includes fracturing of the grains, slips and rotations, will show higher values of solidity due to a higher number of straight boundaries.

The observations shows that low values of the isometrics parameter should be regarded as an effect of mylonitization and dynamic recrystallisation. Moreover, the value of isometrics decreases when fractured fragments of elongated grain aggregates are present. 


\section{CONCLUSIONS}

1. Fault rocks occurring in the Western Tatra Mountains are characterized by strongly heterogeneous fabric and microfabric, which indicates different and changing conditions of pressure, temperature, mechanism and rate of strain during their development.

2. The products of the non-coaxial deformation are the following complexes: 1 - weakly deformed granitoids; 2 - protocataclasites and part of the mesocataclasites formed during block-controlled cataclastic flow; 3 - meso- and ultracataclasites, formed during matrix-controlled cataclastic flow; 4-mylonites and phyllonites.

3. The main processes acting during non-coaxial deformation were: cataclastic grain reduction, cataclastic flow as well as sericitization, and - linked with sericitization - leaching, transport and deposition of silica. Therefore, fault rocks are a product of interaction of the dislocation metamorphism and hydrothermal activity.
4. Marginal zones of the tectonic crystalline sheets were depleted in silica, which produced deformation complexes containing mylonitic schists and phyllonites. These zones form usually negative relief in the contemporary topography.

5. The model of the deformation complexes described is consistent with a new structural interpretation of the Western Tatra Mountains crystalline rocks with thrust tectonics and intense brittle or brittle-ductile non-coaxial Alpine shearing.

6. Grain shape analysis should be considered as a useful tool in reconstruction of the deformation processes. In the fault rocks of the Western Tatra crystalline rocks it shows different rates of deformation and progress.

Acknowledgments. I am grateful to Prof. M. Cieszkowski for critical reading of manuscript and linguistic advice. The paper greatly benefited from constructive reviews by Prof. D. Plašienka, Prof. Z. Cymerman, and an anonymous referee. Thanks are also extended to the Direction of the Tatra National Park for permission to conduct fieldwork.

\section{REFERENCES}

Bac-Moszaszwili M. (1993) Structure of the western termination of the Tatra massif (in Polish with English summary). Annales Societatis Geologorum Poloniae, 63: 167-193.

Bartozzi M., Boyle A., Prior D. (2000) Automated grain boundary detection and classification in orientation contrast images. Journal of Structural Geology, 22: 1569-1579.

Bjørk T., Mair K., Austrheim H. (2009) Quantifying granular material and deformation: advantages of combining grain size, shape, and mineral phase recognition analysis. Journal of Structural Geology, 31: 637-653.

Brodie K., Fettes D., Harte B., Schmid R. (2007) Structural terms including fault rock terms. Recommendations by the IUGS Subcomission on the Systematics of Metamorphic Rocks. Web version of 01.02.07.

Burchart J. (1970) Rocks of the Goryczkowa "crystalline island" in the Tatra Mountains (in Polish with English summary). Studia Geologica Polonica, 32: 1-183.

Carreras J., Cosgrove J., Druguet E. (2013) Strain partitioning in banded and/or anisotropic rocks: Implications for inferring tectonic regimes. Journal of Structural Geology, 50: 7-21.

Childs C., Manzocchi T., Walsh J., Bonson C., Nicol A., Schapfer M. (2009). A geometric model of fault zone and fault rock thickness variations. Journal of Structural Geology, 31: 117-127.

Cymerman Z. (2009a) Sesja terenowa A5. Tektonika alpejska waryscyjskiego krystaliniku Tatr Zachodnich - przykłady od Łuczniańskiej Przełęczy po NW zbocza Wołowca (in Polish). In: LXXIX Zjazd Polskiego Towarzystwa Geologicznego "Budowa geologiczna Tatr i Podhala ze szczególnym uwzględnieniem zjawisk geotermalnych na Podhalu", Bukowina Tatrzańska, 26-29 września 2009 - Materiały konferencyjne: 121-133.

Cymerman Z. (2009b) Sesja terenowa B4. Tektonika krystaliniku Goryczkowej i „czapek” krystalicznych płaszczowiny Giewontu na obszarze Czerwonych Wierchów (in Polish). In: LXXIX Zjazd Polskiego Towarzystwa Geologicznego "Budowa geologiczna Tatr i Podhala ze szczególnym uwzględnieniem zjawisk geotermalnych na Podhalu", Bukowina Tatrzańska, 26-29 września 2009 - Materiały konferencyjne: 174-189.

Cymerman Z. (2011a) Zlokalizowane strefy ścinania na Wołowcu i Jarzabczym Wierchu. In: Tatrzańskie Warsztaty Geologiczne., Zakopane, 13-16 października 2011 (eds. T. Rychliński and P. Jaglarz ): 20-49.

Cymerman Z. (2011b) Próba rekonstrukcji kenozoicznych paleonaprężeń w Tatrach i na Podhalu (in Polish). In: IX Ogólnopolska konferencja z cyklu "Neotektonika Polski" -
Neotektonika Karpat i Polski pozakarpackiej: podobieństwa i różnice, Kraków, 24-25 czerwca 2011 (ed. W. Zuchiewicz): 9-11.

Davis G., Reynolds S. (1996) Structural Geology of Rocks and Regions. John Wiley.

Deditius A. (2004). Characteristics and isotopic age of the muscovites blastesis from the mylonitic zones in the crystalline rocks of the Western Tatra Mountains (in Polish with English summary). Prace Naukowe Uniwersytetu Śląskiego, 16: 121-150.

Druguet E., Alsop G., Carreras J. (2009) Coeval brittle and ductile structures associated with extreme deformation partitioning in a multilayer sequence. Journal of Structural Geology, 31: 498-511.

Engelder J. (1974) Cataclasis and the Generation of Fault Gouge. GSA Bulletin, 85: 1515-1522.

Faryad S. (1999) Metamorphic evolution of the eastern part of the Western Carpathians, with emphasis on Meliata Unit. Acta Montanistica Slovaca, 4: 148-160.

Gawęda A. (2001) Alaskites of the Western Tatra Mountains. A record of Early-Variscan collision stage in the Carpathians precontinent Mountains (in Polish with English summary). Wydawnictwo Naukowe Uniwersytetu Śląskiego, Katowice.

Gawęda A. (2007) Variscan granitoid magmatism in Tatra Mountains - the history of subduction and continental collision. AM monograph, 1: 319-332.

Gawęda A., Burda J. (2004) Evolution of the metamorphism and deformations in the crystalline complex of the Western Tatra Mountains (in Polish with English summary). Prace Naukowe Uniwersytetu Śląskiego, 16: 153-185.

Grochocka-Piotrowska K. (1970) Photointerpretation and genesis of the disjunctive structures in the granite massif of the Polish Tatra Mountains (in Polish with English summary). Acta Geologica Polonica, 20: 365-411.

Guermani A., Pennacchioni G. (1998) Brittle precursors of plastic deformation in a granite: an example from the Mont Blanc massif (Helvetic, western Alps). Journal of Structural Geology, 20: 135-148.

Halfpenny A., Prior D., Wheeler J. (2006) Analysis of dynamic recrystallization and nucleation in a quartzite mylonite. Tectonophysics, 427: 3-14.

Handy M. (1990) The solid state flow of polymineralic rocks. Journal of Geophysical Research, 95: 8647-8661.

Heilbronner R., Keulen N. (2006) Grain size and grain shape analysis of fault rocks. Tectonophysics, 427: 199-216. 
Hippertt J. (1998) Breakdown of feldspar, volume gain and lateral mass transfer during mylonitization of granitoid in a low metamorphic grade shear zone. Journal of Structural Geology, 20: 175-193.

Hirth G., Tullis J. (1992) Dislocation creep regimes in quartz aggregates. Journal of Structural Geology, 14: 145-159.

Ismat Z., Mitra G. (2005) Folding by cataclastic low: evolution of controlling factors during deformation. Journal of Structural Geology, 27: 2181-2203.

Janák M. (1992) Variscan mid-crustal thrusting in the Carpathians I: Metamorphic conditions and P-T paths of the Tatry Mountains. Terra abstracts, Abstract supplement No. 2 to Terra Nova, 4: 35.

Janák M. (1994) Variscan uplift of the crystalline basement, Tatra Mts., central western Carpathians: evidence from ${ }^{40} \mathrm{Ar} /{ }^{39} \mathrm{Ar}$ laser probe dating of biotite and P-T-t paths. Geologica Carpathica, 45: 293-300.

Janák M., Hurai V., Ludhová P., O’Brien J., Horn E.E. (1999) Dehydration melting and devolatization during exhumation of high grade metapelites: the Tatra Mountains, Western Carpathians. Journal of Metamorphic Geology, 17: 379-395.

Janák M., Plašienka D., Petrík I. (2001) Excursion to the Tatra Mountains, Central Western Carpathians: tectonometamorphic records of Variscan and Alpine orogeny. Geolines, 13: 141-148.

Jaroszewski W. (1965) Geology of the upper part of the Kościeliska Valley in the Tatra Mountains (in Polish with English summary). Acta Geologica Polonica, 15: 429-499.

Jaroszewski W. (1967) Geological observations on the rocks of the upper part of the Kościeliska Valley in the Tatra Mountains (in Polish with English summary). Biuletyn Geologiczny Uniwersytetu Warszawskiego, 9: 217-270.

Jones R., Tanner G. (1995) Strain partitioning in transpression zones. Journal of Structural Geology, 17: 793-802.

Jurewicz E. (2000) Tentative reconstruction of the stress axes from the thrust-folding stage in the Tatra Mts on the basis of slickensides in the granitoid core (southern Poland) (in Polish with English summary). Przegląd Geologiczny, 48: 239-246.

Jurewicz E. (2002) Geometric analysis of steep-dipping dislocations within the granitoid core in the Polish part of the Tatra Mts. Annales Societatis Geologorum Poloniae, 72: 89-98.

Jurewicz E. (2005) Geodynamic evolution of the Tatra Mts. and the Pieniny Klippen Belt (Western Carpathians): problems and comments. Acta Geologica Polonica, 55: 295-338.

Jurewicz E., Bagiński B. (2005) Deformation phases in the selected shear zones within the Tatra Mountains granitoid core. Geologica Carpathica, 56: 17-28.

Katz Y., Weinberger R., Aydin A. (2004) Geometry and kinematic evolution of Riedel shear structures, Capitol Reef National Park, Utah. Journal of Structural Geology, 26: 491-501.

Keulen N., Heilbronner R., Stünitz H., Boullier A., Ito H. (2007) Grain size distributions of fault rocks: a comparison between experimentally and naturally deformed granitoids. Journal of Structural Geology, 29: 1282-1300.

Kohút M., Janák M. (1994) Granitoids of the Tatra Mts., Western Carpathians: field relations and petrogenetic implications. Geologica Carpathica, 45: 301-311.

Kruhl J. (2013) Fractal-geometry techniques in the quantification of complex rock structures: A special view on scaling regimes, inhomogeneity and anisotropy. Journal of Structural Geology, 46: $2-21$.

Lin A. (1999) S-C cataclasite in granitic rocks. Tectonophysics, 304: 257-273.

Mahel' M. (1986) Geologická stavba československých Karpát/Paleoalpínske jednotky 1 (in Czech). VEDA, Bratislava.

Michalik A. (1958) Szczegółowa mapa geologiczna Tatr Polskich w skali 1:10 000, arkusz B3 Czerwone Wierchy (in Polish). Wydawnictwa Geologiczne.

Michalik A., Guzik K. (1959a) Szczegółowa mapa geologiczna Tatr Polskich w skali 1:10 000, arkusz C1 Wołowiec (in Polish). Wydawnictwa Geologiczne.
Michalik A., Guzik K. (1959b) Szczegółowa mapa geologiczna Tatr Polskich w skali 1:10 000, arkusz C2, Kamienista (in Polish). Wydawnictwa Geologiczne.

Nemčok M., Marko F., Kovác M., Fodor L. (1989) Neogene tectonics and paleostress changes in the Czechoslovakian part of the Vienna Basin. Jahrbuch der geologischen Bundesanstalt, 132: 443-458.

Nemčok J., Bezák V., Biely A., Gorek A., Gross P., Halouzka R., Janák M., Kahan S., Kotański Z., Lefeld J., Mello J., Reichwalder P., Rączkowski W., Roniewicz P., Ryka W., Wieczorek J., Zelman J. (1994) The geological map of the Tatra Mountains 1:50 000. Štátny geologický ústav Dionýza Štúra.

Passchier C., Trouw R. (2005) Microtectonics. Springer, 2nd, revised and enlarged edition.

Piotrowska K. (2009) Wykaz jednostek strukturalnych Tatr (in Polish). In: LXXIX Zjazd Polskiego Towarzystwa Geologicznego "Budowa geologiczna Tatr i Podhala ze szczególnym uwzglednieniem zjawisk geotermalnych na Podhalu", Bukowina Tatrzańska, 26-29 września 2009 - Materiały konferencyjne: 27-28.

Plašienka D. (1995) Passive and active margin history of the northern Tatricum (Western Carpathians, Slovakia). Geologische Rundschau, 84: 748-760.

Plašienka D. (2003) Development of basement-involved fold and thrust structures exemplified by the Tatric-Fatric-Veporic nappe system of the Western Carpathians (Slovakia). Geodinamica Acta, 16: 21-38.

Poller U., Janák M., Kohút M., Todt W. (2000) Early Variscan magmatism in the Western Carpathians: U-Pb zircon data from granitoids and orthogneisses of the Tatra Mountains (Slovakia). International Journal of Earth Sciences, 89: 336-349.

Roduit N. (2007) JMicroVision: un logiciel d'analyse d'images pétrographiques polyvalent. PhD thesis, Université de Geneve (in French with English summary) http://www.jmicrovision.com/examples/these.pdf

Sibson R. (1977) Fault rocks and fault mechanisms. Journal of Geological Society, 133: 191-213.

Skupiński A. (1975) Petrogenesis and structure of the crystalline core between Ornak and Rohacze, Western Tatra Mts (in Polish with English summary). Studia Geologica Polonica, 49: 1-105.

Uchman A. (2009) Stratygrafia i sedymentologia utworów mezozoiku Tatr i Podhala (in Polish). In: LXXIX Zjazd Polskiego Towarzystwa Geologicznego "Budowa geologiczna Tatr i Podhala ze szczególnym uwzględnieniem zjawisk geotermalnych na Podhalu", Bukowina Tatrzańska, 26-29 września 2009 Materiały konferencyjne: 9-26.

Vigneresse J., Tikoff B. (1999) Strain partitioning during partial melting and crystallizing felsic magmas. Tectonophysics, 312: $117-132$.

White S. (2001) Textural and microstructural evidence for semi-brittle low in natural fault rocks with varied mica contents. International Journal of Earth Sciences, 90: 14-27.

Wibberley C. (1999) Are feldspar-to-mica reactions necessarily reaction-softening processes in fault zones? Journal of Structural Geology, 21: 1219-1227.

Williams M., Melis E., Kopf C., Hanmer S. (2000) Microstructural tectonometamorphic processes and the development of gneissic layering: a mechanism for metamorphic segregation. Journal of Metamorphic Geology, 18: 41-57.

Wilson C., Evans L., Delle Piane C. (2009) Modelling of porphyroclasts in simple shear and the role of stress variations at grain boundaries. Journal of Structural Geology, 31: 1350-1364.

Wintsch R. (1995) Fluid-rock reaction weakening of fault zones. Journal of Geophysical Research, 100: 13 021-13 032

Woodcock N., Mort K. (2008) Classification of fault breccias and related fault rocks. Geological Magazine, 145: 435-440. 